\title{
Direct contact membrane distillation for the concentration of saline dairy effluent
}

Kezia Kezia ${ }^{1}$, Judy Lee ${ }^{1}$, Mike Weeks ${ }^{2}$, Sandra Kentish ${ }^{1 *}$

1. Dairy Innovation Research Hub, Department of Chemical and Biomolecular Engineering, The University of Melbourne, Victoria 3010.

2. Dairy Innovation Research Hub, Dairy Innovation Australia Limited, 180 Princes Hwy, Werribee, VIC, Australia 3030

* Corresponding Author: sandraek@unimelb.edu.au

\section{Abstract}

The ability of direct contact membrane distillation to concentrate the waste effluent from salty whey, a by-product from the cheese making industry has been investigated. The effect of trace protein in the feed, cross-flow velocity and feed acidity were the factors examined. Flat Sheet PTFE membranes of nominal pore sizes $0.05,0.22$ and $0.45 \mu \mathrm{m}$ were utilised. A decline in feed flux In the presence of trace protein in the feed was observed, but liquid penetration through the membrane could still be prevented by utilization of a membrane of smaller pore size, to achieve a final total solids concentration of $\pm 30 \% \mathrm{w} / \mathrm{w}$ with water recovery from $37-83 \%$. The pressure-drop across the channel length was also predicted accounting for the feed spacer. To increase the channel length up to $1 \mathrm{~m}$ will require operation using the smallest pore size of $0.05 \mu \mathrm{m}$, unless very low cross-flow velocities are used. The fouling of the membrane is primarily governed by precipitation of a calcium phosphate salt. However, operation at low $\mathrm{pH}$ does not improve the flux or the final salt concentration significantly.

Keywords: Membrane distillation, dairy salts, pressure drop, fouling. 


\begin{tabular}{|c|c|c|}
\hline \multicolumn{3}{|c|}{ Nomenclature } \\
\hline & Description & $\underline{\text { SI unit }}$ \\
\hline B & Pore geometric factor & - \\
\hline C & Molar concentration & $\mathrm{mol} / \mathrm{m}^{3}$ \\
\hline c & Salt concentration & $\mathrm{g} / \mathrm{L} \mathrm{NaCl}$ equivalent \\
\hline$C_{t d}$ & Total Drag & \\
\hline$d_{H}$ & Hydraulic diameter & $\mathrm{m}$ \\
\hline$f$ & Fanning friction Factor & \\
\hline $\mathrm{j}_{\mathrm{v}}$ & Water flux & $\mathrm{kgm}^{-2} \mathrm{~s}^{-1}$ \\
\hline $\mathrm{k}_{\mathrm{cp}}$ & Mass transfer coefficient & $\mathrm{ms}^{-1}$ \\
\hline $\mathrm{K}_{\mathrm{m}}$ & Overall mass transfer coefficient & $\mathrm{ms}^{-1}$ \\
\hline LEP & Liquid entry pressure & $\mathrm{Pa}$ \\
\hline$L_{\text {mesh }}$ & Mesh element length & $\mathrm{m}$ \\
\hline $\mathrm{N}$ & Mass flux & $\mathrm{kg} \mathrm{m}^{-2} \mathrm{~s}^{-1}$ \\
\hline $\operatorname{Re}$ & Reynolds number & - \\
\hline$r_{\text {pore }}$ & Pore radius & $\mathrm{m}$ \\
\hline Sc & Schmidt number & - \\
\hline Sh & Sherwood number & - \\
\hline u & Tangential velocity & $\mathrm{m} / \mathrm{s}$ \\
\hline V & Tank Volume & $\mathrm{L}$ \\
\hline$\mu$ & Viscosity & Pa.s \\
\hline 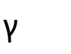 & Liquid surface tension & N. $\mathrm{m}^{-1}$ \\
\hline$\Delta \mathrm{P}_{\mathrm{m}}$ & Pressure drop across the membrane & $\mathrm{Pa}$ \\
\hline$\theta$ & Liquid-surface contact angle & 0 \\
\hline$\rho$ & Density & $\mathrm{Kg} \cdot \mathrm{m}^{-3}$ \\
\hline \multicolumn{3}{|c|}{ Subscripts } \\
\hline b & Bulk & \\
\hline$d$ & Permeate tank & \\
\hline$f$ & Final & \\
\hline$F$ & Feed & \\
\hline i & Initial & \\
\hline $\mathrm{m}$ & Membrane surface & \\
\hline $\mathrm{p}$ & Permeate & \\
\hline
\end{tabular}




\section{Introduction}

The increasing salinity of inland waterways is a major environmental issue in Australia and the generation of saline waste in dairy processing adds to this problem. The dairy industry is one of the largest rural industries in Australia and produces $10.3 \mathrm{GL} / \mathrm{y}$ of high salinity effluent (Wilkinson et al. 2004). Salty whey, a by-product of hard cheese manufacture, contributes to this effluent load. The salt concentration ranges from 3 to $19 \% \mathrm{w} / \mathrm{w}$, while the protein and fat concentration is commonly lower than 1\% w/w (Blaschek et al. 2007). Through the use of low energy ultrafiltration (UF), the traces of fat and protein can be completely removed, yet a large volume of saline waste is still generated. This is a paramount issue since direct discharge of this salty effluent to the environment would disrupt the ecological balance. As a consequence, the effluent must either be diluted with less salty streams before discharge, or alternatively concentrated and then evaporated to dry solids within a waste treatment pond.

Reverse osmosis (RO) is widely utilized for the concentration step. Nonetheless, as the osmotic pressure increase, the efficiency of RO decreases. An emerging alternative is membrane distillation (MD) (Alkhudhiri et al. 2012a, Alkhudhiri et al. 2012b, Alklaibi and Lior 2005, Angela et al. 2011, Bandini et al. 1992, Bandini and Sarti 1999, Curcio and Drioli 2005, Fane et al. 1987, Findley 1967, Gostoli et al. 1987, Gryta 2012, Gryta et al. 2013, Hausmann et al. 2012, Hausmann et al. 2013, Hsu et al. 2002, Khayet et al. 2007, Khayet Souhaimi and Matsuura 2011, Schofield et al. 1990, Tomaszewska 2000, Van der Bruggen and Vandecasteele 2002, Yun et al. 2006). The use of membrane distillation at a large scale is still rare; however it has the potential to concentrate the waste stream to higher solid levels than an RO process.

An advantage of this process compared to conventional pressure-driven filtration is that it requires only low pressures and moderate temperatures and thus can utilize a membrane with lower mechanical strength (Burgoyne and Vahdati 2000, Fritzmann et al. 2007, Khawaji et al. 2008). 
Furthermore, MD can theoretically achieve $100 \%$ rejection of salts and particulates i.e. only volatile solvents in the vapour form are able to travel through the membrane, Finally, as the process operates at only moderate temperatures it can be readily driven by waste heat or solar energy.

Unlike pressure-driven filtration, the mass flux across the membrane $(\mathrm{N})$ in MD is driven by the water vapour partial pressure difference across the membrane $\left(\Delta P_{m}\right)$, which is essentially influenced by the temperature gradient on the membrane surfaces (Equation 1).

$$
\text { Eq 1. } N=K_{m} \Delta P_{m}
$$

where $K_{m}$ is the mass transfer coefficient of water vapour through the membrane itself. The vapour pressure of water on the feed side is also affected by the solute concentration. With a significant increase in solute (salt) concentration, the water activity will fall resulting in a reduction of this partial pressure and thus a loss in partial pressure driving force.

The MD process uses a porous membrane with pore sizes comparable to that of microfiltration or ultrafiltration (Laganà et al. 2000, Lawson and Lloyd 1997, Martínez-Díez and Vázquez-González 1999, Martínez-Díez et al. 1998, Zhang et al. 2010). The membrane pores must not be wetted by the feed solution. Pore wetting leads to deterioration of permeate quality as liquid crosses the interface. The susceptibility towards pore wetting can be characterised by the liquid entry pressure (LEP) of the membrane. This is the pressure where liquid first penetrates through the membrane pores. It can be measured experimentally, but also predicted by the Laplace-Kelvin equation as follows:

$$
\mathrm{Eq} 2 . L E P=-\frac{2 B \gamma_{L} \cos \epsilon}{r_{\text {pore }}}
$$

Where $B$ is a factor representing the pore geometry $(0<B<1$, unity for a cylindrical pore $), \nu_{L}$ is the liquid surface tension, $\theta$ the liquid/membrane contact angle and $r_{\text {pore }}$ is the maximum pore radius (Khayet Souhaimi and Matsuura 2011, Lawson and Lloyd 1997). As indicated by Eq 2, pore wetting can be minimised by using a hydrophobic membrane material of a uniform, small pore size (Kayet and Matsuura 2011, Lawson and Lloyd 1997, Mulder 1996, Siminoni 2010, Simioni 2010). 

efficiency of heat and mass transfer. Temperature polarization causes a temperature reduction from the bulk feed (hot side) to the feed side membrane surface, while concentration polarization causes the salt concentration to build up within this boundary layer. The mass transfer coefficient within the concentration polarisation boundary layer $\left(k_{c p}\right)$ is governed by the cross-flow velocity (CFV). This mass transfer coefficient can be estimated using a dimensionless mass-transfer correlation (Equation 4).

For a slit channel with net spacer equipped, $A=0.664, x=0.55, y=0.33, z=0.5$ (Da Costa et al. 1994). The Sherwood number, $S h=\frac{k_{C p} d_{H}}{D}$ where $D$ is the diffusion coefficient and $d_{H}$ is the hydraulic mean diameter. The Reynolds number, $R e=\rho u \frac{d_{H}}{\mu}$, the Schmidt Number, $S c=\frac{\mu}{\rho D}$, and $u=C F V . L_{\text {mesh }}$ is the length of the mesh element.

This estimate of the mass transfer coefficient can be used to determine the polarisation ratio, which relates the bulk solute concentration $\left(C_{b}\right)$ to that at the surface of the membrane $\left(C_{m}\right)$, given the solution density $(\rho)$ and the permeate volumetric flux $\left(j_{v}\right)$ is known:

$$
\text { Eq 4. } \frac{c_{m}}{c_{b}}=\exp \left(\frac{j_{v}}{\rho k_{c p}}\right)
$$

The membrane polymer matrix itself can also act to conduct heat from the hot to the cold side reducing energy efficiency. To reduce this, a membrane of high porosity, low tortuosity and low polymer thermal conductivity (Khayet Souhaimi and Matsuura 2011, Souhaimi and Matsuura 2011) should be used. To satisfy these characteristics, hydrophobic microporous materials such as polypropylene (PP), polydivinyldenedifluoride (PVDF) and polytetrafluoroethylene (PTFE) form the most adequate membranes.

The focus of this study is to assess the ability of direct contact membrane distillation to concentrate the saline waste stream generated as a by-product of cheese making and containing 
high concentrations of salt and lactose; and trace amounts of protein. The effect of trace protein on the permeate flux and pore breakthrough is investigated. As a hydrophobic membrane material is utilized, protein analyses are crucial since protein will be strongly attracted to the membrane surface and this could lead to liquid penetration into the pores, or fouling of the membrane surface. Previous work has shown that mineral scaling can also be a significant issue in concentrated salt solutions with respect to both pore breakthrough and membrane fouling(Edwie and Chung 2012). We investigate this issue by observing the system performance at low $\mathrm{pH}$, as this approach is known to eliminate calcium salt scaling in dairy systems(Rice et al. 2009a). Furthermore, the impact of cross-flow velocity on flux, pore breakthrough and pressure drop is considered.

\section{Materials and methods}

\subsection{Materials}

Polytetrafluoroethylene (PTFE) membranes with a polypropylene (PP) non-woven support layer were used. The membranes were supplied by Sterlitech as dry coupons with pore sizes $0.05 \mu \mathrm{m}, 0.2$ $\mu \mathrm{m}$ and $0.45 \mu \mathrm{m}$. The membranes were cut to size and used without any pretreatment.

For ultrafiltration pre-treatment, a polyethersulfone (PES) membrane of pore size 10kDa was used (Koch), while for microfiltration pre-treatment, a PES membrane with pore size $0.1 \mu \mathrm{m}$ (Koch) was utilised. Both membranes were preserved in glycerol and so prior to use the membrane was flushed with deionised water to remove this preservative.

All chemical reagents utilized were analytical grade. Sodium hydroxide pellets, hydrochloric acid $(\mathrm{HCl}, 37.0 \%)$, sodium chloride $(\mathrm{NaCl},>99 \%)$, magnesium chloride hexahydrate $\left(\mathrm{MgCl}_{2} \cdot 6 \mathrm{H}_{2} \mathrm{O},>99 \%\right)$, potassium chloride $(\mathrm{KCl},>99 \%)$ and calcium chloride dihydrate $\left(\mathrm{CaCl}_{2} \cdot 2 \mathrm{H}_{2} \mathrm{O},>99 \%\right)$ were purchased from Chem Supply.

Bovine serum albumin (BSA, >99\%) for Bradford analysis was supplied by Sigma Aldrich and concentrated dye reagent from BioRad. Precast Tris- $\mathrm{HCl}$ gel $12 \%$ gradient, 20x Tris-Glycine SDS, $4 x$ 
sample buffer, molecular weight standard SeeBlue plus2 were supplied by Novex, Life Science Technology.

Purified water utilized for filtration experiments and cleaning had a resistivity greater than $15.5 \mathrm{M} \Omega$ cm (Millipore Elix), while buffer, stock solutions and standards for analysis were prepared using water with resistivity greater than $18.2 \mathrm{M} \Omega$-cm (Millipore MilliQ).

Salty whey effluent was kindly supplied from two different dairy factories in Victoria Australia and these samples are labelled here as B1, B2, B3 and B4. The streams are a by-product from the production of various hard cheese types. The B1, B2 and B4 samples were drawn from the permeate stream of an ultrafiltration unit used to recover saleable protein from the salty whey. Conversely, sample B3, was received prior to any filtration. Hence, upon arrival in our laboratory, the excess top layer of fat was removed from this sample using a centrifuge. The supernatant was then filtered using a $0.1 \mu \mathrm{m}$ microfiltration membrane (Koch) to remove residual fat and protein. In each case, the effluent sample was transported in a refrigerated truck and then stored at $4^{\circ} \mathrm{C}$ until use. Each solution was used within 4-6 weeks of delivery.

\subsection{Methods}

Direct contact membrane distillation was conducted in a counter-current configuration to maintain the temperature gradient. The schematic diagram of the MD rig is depicted in Figure 1. The filtration cell was constructed using polycarbonate material to avoid excessive heat loss to the environment with an active membrane area of $0.014 \mathrm{~m}^{2}(14.6 \mathrm{~cm} \times 9.5 \mathrm{~cm})$. The feed and permeate channel depths were each $0.97 \mathrm{~mm}$ to accommodate a low foulant 17 mil diamond type feed spacer (spacer porosity, $\varepsilon=0.5$, Mesh length, $L_{\text {mesh }}=0.000432 \mathrm{~m}$, hydraulic mean diameter, $d_{H}=2.41 \times 10^{-4}$ m, calculated from formulae provided in Da Costa et al.(1994), Sterlitech. USA). Heated feed solution was circulated to the bottom compartment at $50^{\circ} \mathrm{C}$, whereas the cold clean water permeate stream was provided to the top compartment at $10^{\circ} \mathrm{C}$. Due to heat transfer effects, 
the temperature on the hot side typically fell from $50^{\circ} \mathrm{C}$ to $44^{\circ} \mathrm{C}$ across the module length and for the cold side it increased from $10^{\circ} \mathrm{C}$ to $16^{\circ} \mathrm{C}$. The PTFE (active)/PP(support) membrane was mounted with the active side facing the hot feed stream.

The feed and permeate flows were delivered using positive displacement gear pumps - a Hydracell M03 on the feed side and a Micropump-83589 in the permeate line. Temperature and pressure indicators (Swagelok) were installed in the inlet and outlet stream of both the feed and permeate side. Back pressure regulators were installed in the return lines of feed and permeate but remained fully open throughout experiments. The inlet feed pressure ranged between $20 \mathrm{kPa}$ to $110 \mathrm{kPa}$ gauge at the initial feed concentration, dependent upon the crossflow velocity. This pressure reached 25 to $152 \mathrm{kPa}$ gauge at the highest solute concentration at the end of each experiment. The permeate pressure ranged from $20 \mathrm{kPa}$ to $120 \mathrm{kPa}$ gauge for cross flow velocities from 0.13 to 0.27 $\mathrm{m} / \mathrm{s}$.

Permeate flux was measured by recording the mass change of the permeate tank (every 100s) using an O'Hauss Balance with data logger. The conductivity within this tank was recorded using a conductivity meter (CRISON-GLP 31) every 300s. This conductivity was converted to an equivalent $\mathrm{NaCl}$ concentration $\left(c_{d}\right)$ based on a calibration curve. The permeate tank contains an initial volume of around two litres of cold water $\left(V_{p i}\right)$, so the actual permeate salt concentration is calculated after subtraction of this volume of water from the final tank volume $\left(V_{p f}\right)$ i.e.:

$$
\text { Eq } 5 \cdot c_{p}=c_{d}\left(\frac{V_{p f}}{V_{p f}-V_{p i}}\right)
$$

The water recovery was calculated from the change in the total solids concentration in the feed tank $\left(c_{F}\right)$ between the beginning (i) and the end(f) of the experiment:

$$
\text { Eq 6. Recovery }=\frac{\left(1-c_{F f}\right) v_{F f} / V_{F i}-\left(1-c_{F i}\right)}{1-c_{F i}}
$$

where $V_{F}$ represents the volume in the feed tank. 
The cleaning-in-place (CIP) of the membrane was conducted by circulating solutions in an acid-baseacid cleaning cycle as the major foulant was mineral scaling, with only a low concentration of organic protein. The concentrated acid cleaning agent consisted of $30 \% \mathrm{HNO}_{3}$ and $30 \% \mathrm{H}_{3} \mathrm{PO}_{4}$ whereas the concentrated alkaline cleaning agent was made of $10 \% \mathrm{NaOH}$ and $10 \%$ EDTA (ethylenediaminetetraacetic sodium salt). The acid cleaning was conducted at $\mathrm{pH} 3$ and $\mathrm{pH} 11$ for alkaline cleaning. The membrane was then air-dried to recover its hydrophobicity. In each case, this cleaning cycle allowed the membrane flux to be fully recovered. However each membrane was discarded after 3 to 5 experiments due to mechanical damage arising from the repetitive mounting and dismounting in the membrane cell.

For both MF and UF processes, a stainless-steel cell (Sterlitech Sepa CFII, active membrane area $0.014 \mathrm{~m}^{2}, 14.6 \mathrm{~cm} \times 9.5 \mathrm{~cm}$ ) was used with the same Hydracell M-03 pump to deliver a feed flow of $\approx$ 3.7 L $/ \mathrm{min}(\mathrm{CF} \approx 0.7 \mathrm{~m} / \mathrm{s})$. A high foulant PTFE spacer (65 mil diamond type) was used on the feed side to enhance turbulence and minimize fouling. The process was carried out at temperature $\approx 10^{\circ} \mathrm{C}$ with inlet pressure 200 and 400-500 kPa for MF and UF respectively.

The liquid entry pressure (LEP) of the membrane was measured using a dead-end filtration cell. An unused membrane was mounted with the active side facing the liquid and the working liquid (salty whey) was pressurised perpendicular to the membrane using compressed air. The pressure was increased until the first droplet of liquid was observed on the support side. The LEP experiment was conducted at $50^{\circ} \mathrm{C}$, to synchronize with the actual results from the MD experiment.

Total solids were determined by recording sample weights before and after drying samples in an oven at $110^{\circ} \mathrm{C}$. The total organic content was then determined by ashing at $600^{\circ} \mathrm{C}$ in a furnace and again recording the sample weight. The cation concentrations in the solution were analysed using Inductively coupled plasma (ICP-OES 720ES, Varian). The instrument detection limit is $0.03 \mu \mathrm{g} / \mathrm{L}$ for Ca, $1 \mu \mathrm{g} / \mathrm{L}$ for $\mathrm{Na}, 10 \mu \mathrm{g} / \mathrm{L}$ for $\mathrm{K}$ and $0.1 \mu \mathrm{g} / \mathrm{L}$ for $\mathrm{Mg}$ (Varian 1991). The mineral analysis was conducted using UF permeate samples to avoid interference from proteins. Sugar analysis was conducted using High performance liquid chromatography (Shimadzu RP-HPLC), using a 
monosaccharide analytical column (Phenomenex Razek $\mathrm{RCM} \mathrm{Ca}{ }^{2+} 8 \%, 300 \times 7.8 \mathrm{~mm}$ ). A refractive index detector (RID) was utilized with water $(0.5 \mathrm{~mL} / \mathrm{min})$ as the carrier at a column temperature of $80^{\circ} \mathrm{C}$

To analyse the composition of the mineral foulant deposited on the membrane, the fouled membrane was first rinsed three times using 1-propanol to wash off the excess aqueous liquid. The fouled membrane was then immersed in concentrated nitric acid $\left(\mathrm{HNO}_{3}, 15.6 \mathrm{M}\right.$, Scharlau) overnight and the proportions of $\mathrm{Na}, \mathrm{Ca}$ and $\mathrm{P}$ in the acid solution then determined using Inductively coupled plasma atomic emission spectroscopy (720ES Varian). A Scanning Electron Microscope (Quanta FEG 200 ESEM) with EDX Scanner was utilized for surface observation of the membrane. The sample was mounted on a carbon stub uncoated. The imaging was conducted under low vacuum conditions.

The total protein was quantified using the Bradford UV-absorbance technique at wavelength $595 \mathrm{~nm}$ (Bradford 1976). The pre-filtered sample was diluted to ensure absorbance in the range from 0.05 to 1. The reagent was supplied as a concentrate and was diluted with water at a ratio 1:4 . A $100 \mu \mathrm{L}$ of either diluted sample or protein standard (Bovine Serum Albumin, BSA, Sigma Aldrich) was added to $5 \mathrm{~mL}$ of dye reagent. The sample tubes were vortexed and the absorbance was measured at $595 \mathrm{~nm}$ with a $1 \mathrm{~cm}$ path length using a disposable plastic cuvette. The BSA standard calibration curve was linear for protein concentrations of $0.2-1 \mathrm{mg} / \mathrm{mL}$. The interaction of dairy protein with the dye might be different to the interaction between BSA and dye which may compromise the accuracy. Nonetheless, this method gives an initial approximation of the total protein. The protein composition was further investigated using sodium dodecyl sulphate polyacrylamide gel electrophoresis (SDS-PAGE). The sample was mixed with $4 \mathrm{x}$ sample buffer containing $0.1 \mathrm{M}$ dithiothreitol to cleave disulfide bonds. The sample was boiled for five minutes and loaded into the pre-cast $12 \%$ Tris- $\mathrm{HCl}$ Criterion gel. A constant voltage of $125 \mathrm{~V}$ was applied for 70 mins. Proteins were identified by comparing the results to that of standard proteins (SeeBlue plus2). 


\subsection{Characterisation of Salty Whey Effluent}

234 The mineral, protein and sugar content of the four salty whey samples, is shown in Table 1. Data for samples B1, B2 and B4 are for the UF permeate as delivered directly from the dairy factory. Data for sample B3 is after centrifugation and MF in our laboratory to remove suspended solids and fat.

Table 1. Composition of the salty-whey.

\begin{tabular}{|l|c|c|c|c|}
\hline Sample & $\begin{array}{c}\text { Total } \\
\text { Organic } \\
(\%)\end{array}$ & $\begin{array}{c}\text { Ash } \\
(\%)\end{array}$ & $\begin{array}{c}\text { Total Solid } \\
(\%)\end{array}$ & $\begin{array}{c}\text { Titratable } \\
\text { Acidity } \\
w / v \%\end{array}$ \\
\hline B1 & $2.5 \pm 0.4$ & $3.3 \pm 0.1$ & $5.8 \pm 0.5$ & $0.58 \pm 0.11$ \\
\hline B2 & $1.8 \pm 0.1$ & $9.6 \pm 0.4$ & $11.4 \pm 0.5$ & $0.58 \pm 0.11$ \\
\hline B3 & $2.8 \pm 0.7$ & $4.9 \pm 0.8$ & $7.7 \pm 0.7$ & $0.09 \pm 0.01$ \\
\hline B4 & $2.1 \pm 0.3$ & $6.5 \pm 0.4$ & $8.6 \pm 0.7$ & $0.10 \pm 0.03$ \\
\hline
\end{tabular}
B1, B2 and B4 as received from the factory. B3 after laboratory MF.

For some experiments, further ultrafiltration was conducted in the laboratory to remove any residual protein. As shown in Figure 2, protein concentrations were negligible after this step, as also confirmed with the Bradford method. This result is not unexpected, as the smallest whey-protein constituent i.e. $\alpha$-lactalbumin $(\approx 14.2 \mathrm{kDa})$ is larger than the membrane pore size $(10 \mathrm{kDa})$. Furthermore, after this UF step, the fat content of all samples were also found to be negligible $(<0.1$ $\mathrm{g} / \mathrm{L})$.

Aside from protein and fat, sugar and minerals are present in the system and both components can

250 influence the MD process. The sugars are mainly lactose (disaccharide) but further di/trisaccharide peaks were also detected. These sugars could not be reliably identified, so are listed in Table 1 as 
Table 2. Mineral composition of the salty-whey.

\begin{tabular}{|l|c|c|c|c|c|c|c|}
\hline & $\begin{array}{c}\mathrm{Na} \\
\mathrm{g} / \mathrm{L}\end{array}$ & $\begin{array}{c}\mathrm{Ca} \\
\mathrm{g} / \mathrm{L}\end{array}$ & $\begin{array}{c}\mathrm{K} \\
\mathrm{g} / \mathrm{L}\end{array}$ & $\begin{array}{c}\mathrm{Mg} \\
\mathrm{g} / \mathrm{L}\end{array}$ & $\begin{array}{c}\mathrm{Cl} \\
\mathrm{g} / \mathrm{L}\end{array}$ & $\begin{array}{c}\mathrm{P} \\
\mathrm{g} / \mathrm{L}\end{array}$ & $\begin{array}{c}\text { Conductivity } \\
\mathrm{ms} / \mathrm{cm}\end{array}$ \\
\hline B1 & $11.2 \pm 1.3$ & $2.0 \pm 0.2$ & $1.5 \pm 0.1$ & $0.5 \pm 0.004$ & $17.4 \pm 0.7$ & $0.25 \pm 0.1$ & $39-43$ \\
\hline B2 & $32.5 \pm 4.8$ & $1.6 \pm 0.2$ & $1.7 \pm 0.1$ & $0.1 \pm 0.004$ & $50.2 \pm 2.2$ & $0.43 \pm 0.02$ & $110-127$ \\
\hline B3 & $17.0 \pm 1.7$ & $1.4 \pm 0.2$ & $1.1 \pm 0.1$ & $0.1 \pm 0.006$ & $26.1 \pm 1.9$ & $0.41 \pm 0.08$ & $66-74$ \\
\hline B4 & $23.7 \pm 1.1$ & $1.8 \pm 0.2$ & $1.6 \pm 0.4$ & $0.2 \pm 0.01$ & $30.0 \pm 1.4$ & $0.35 \pm 0.02$ & $82-83$ \\
\hline
\end{tabular}

\subsection{Liquid Entry Pressure}

The liquid entry pressure at $50^{\circ} \mathrm{C}$ for the salty whey effluent was determined for all three membrane pore sizes, before and after ultrafiltration (Figure 3). The pore size of the membrane is as reported

by the supplier (Sterlitech USA).

There is some discrepancy between the measured LEP and that calculated from the Laplace-Kelvin equation (Eq 2) for pure water. The discrepancy may reflect the assumption that $B=1$ i.e. cylindrical geometry. In reality, the PTFE membrane pores are more elongated or slit shaped (image not shown) so that $B$ is lower, $0<B<1$ (Siminoni 2010). Furthermore, the contact angle between water and the membrane was measured at ambient temperature which also leads to inaccuracy in the value calculated using the Laplace-Kelvin equation.

The experimental LEP of pure water is more than double that of the salty whey waste even for the UF pre-treated solution. As the LEP measurement is conducted by applying pressure perpendicular to the membrane, the potential foulants, in this case the high concentration of mineral and sugars, are also pushed through the pore which reduces the surface hydrophobicity. The LEP is greater for the B1 sample after ultrafiltration pretreatment, indicating that pore wetting is influenced by the presence of $>2 \mathrm{~g} / \mathrm{L}$ of protein. For the B2 sample, the differences caused by ultrafiltration are small and generally within experimental error. This is not unexpected, as the original protein content of sample B2 was low. The effect of salt concentration on the LEP can be observed by comparing the 
data for samples B1 and B2 after UF. In this case, as the salt concentration increases the LEP value falls from $175 \mathrm{kPa}$ (B1 after UF, 3wt \% salt) to $168 \mathrm{kPa}$ (B2 after UF, $10 \mathrm{wt} \%$ salt), for a $0.5 \mu \mathrm{m}$ membrane.

\subsection{Membrane Distillation}

In a typical MD process, the permeate flux remains relatively stable for several hours, before declining rapidly and then reaching a second period of steady state operation at a much lower flux (

Figure 4). Similar behaviour has been recorded in other work (Martínez and Rodríguez-Maroto 2007, Tun et al. 2005, Yun et al. 2006, Zhang 2011). Mathematical modelling using the approach outlined by Schofield et al 1990 (Schofield et al. 1990), confirms that the consistently small decline in flux in the early stable region can be readily explained by the decrease in water activity as the solids concentration increases, which reduces the driving force for evaporation (Equation 1). However, such changes in water activity cannot explain the subsequent rapid decline in flux. Rather, it appears that this relates to the solution at the surface of the membrane reaching saturation and salt crystals beginning to form. Due to concentration polarisation, the concentration at the membrane surface can be significantly higher than in the bulk solution. Yun et al. (Yun et al. 2006) find that the onset of the rapid decline occurs at about $26 \mathrm{wt} \%$ solids in the bulk solution for a pure $\mathrm{NaCl}$ solution, while in the present case, the decline is initiated at a bulk salts concentration of around $15-20 \mathrm{wt} \%$. This difference reflects the more complex nature of the salt mixture in the present case. Once the solution at the membrane surface is saturated, the deposition of salts may also lead to an additional fouling resistance (Tun et al. 2005, Yun et al. 2006). Further water evaporation occurs at a constant low value, reflecting a balance between water removal and salt crystallisation to maintain the solidliquid equilibria.

In previous work with sugar solutions (Martínez and Rodríguez-Maroto 2007, Schofield et al. 1990), the flux decline has also been attributed to increases in solution viscosity. However, in the present case, the experimentally measured changes in viscosity (data not shown) are insufficient to significantly contribute to the observed flux reductions. 
At the beginning of the experiment, the flux for a salty whey waste solution containing $>2 \mathrm{mg} / \mathrm{ml}$ protein is approximately $15 \%$ lower compared to the solution after further ultrafiltration to remove this protein (Figure 4). A region of constant flux region is observed for \pm 10 hours operating time for the UF treated sample whereas a gradual decrease in flux is observed for the untreated solution. This gentle decrease in the early region is probably associated with membrane protein fouling. The hydrophobic membrane is susceptible to deposition of organics which compromises the membrane efficiency and lowers the breakthrough pressure (LEP), as described above. However, significant liquid penetration through the $0.2 \mu \mathrm{m}$ membrane did not occur even after approximately 20 hours operation, as this would be indicated by a rapid, substantial increase in permeate flux and a reduction in permeate quality. The TMP (transmembrane pressure) at the end of experiment is an average of $80 \mathrm{kPa}$ with the highest pressure differential at the feed inlet point of $90 \mathrm{kPa}$. The LEP for this system is $135 \pm 14 \mathrm{kPa}$ (Figure 3). Therefore throughout the experiment liquid penetration was not expected.

Even a small trace of protein residue appears to influence the MD performance. This is evident from Figure 5 and Table 3, which compares the performance of a single batch of whey (B2) before and after further ultrafiltration (UF) to remove protein, processed with three different pore sizes. As expected, the flux increases with pore size, as the resistance to mass transfer is lowered. However, the flux in the early hours of each run is also clearly higher for the whey without protein than that containing $0.3 \mathrm{mg} / \mathrm{ml}$. For the runs with 0.05 and 0.2 micron pore size, liquid penetration was not a major issue even with the trace of protein. A high permeate quality was achievable with the $0.05 \mu \mathrm{m}$ membrane, whereas for the $0.2 \mu \mathrm{m}$ the permeate quality is slightly compromised, as shown in Table 3. 

protein) as a function of pore size.

\begin{tabular}{|c|c|c|c|c|}
\hline $\begin{array}{c}\text { Pore size } \\
(\mu \mathrm{m})\end{array}$ & $\begin{array}{c}\text { Trace } \\
\text { protein }\end{array}$ & $\begin{array}{c}\text { Permeate Flux } \\
\text { After three hours } \\
\left(\mathrm{kg} / \mathrm{m}^{2} \mathrm{~h}\right)\end{array}$ & $\begin{array}{c}\text { Conductivity of } \\
\text { the permeate } \\
\text { tank } \\
\text { (with dilution) }\end{array}$ & $\begin{array}{c}\text { Calculated } \\
\text { permeate } \\
\text { concentration } \\
\text { (equivalent g/L } \\
\text { NaCl) }\end{array}$ \\
\hline 0.05 & $0.3 \mathrm{mg} / \mathrm{ml}$ & 7 & $250 \pm 88 \mu \mathrm{s} / \mathrm{cm}$ & 0.3 \\
0.2 & $0.3 \mathrm{mg} / \mathrm{ml}$ & 12 & $773 \pm 36 \mu \mathrm{s} / \mathrm{cm}$ & 0.8 \\
0.45 & $0.3 \mathrm{mg} / \mathrm{ml}$ & 20 & $3.9 \pm 1.4 \mathrm{~ms} / \mathrm{cm}$ & 3.6 \\
\hline 0.05 & $\mathrm{Nil}$ & 9 & $80 \pm 27 \mu \mathrm{s} / \mathrm{cm}$ & 0.1 \\
0.2 & $\mathrm{Nil}$ & 15 & $159 \pm 89 \mu \mathrm{s} / \mathrm{cm}$ & 0.2 \\
0.45 & $\mathrm{Nil}$ & 22 & $175 \pm 62 \mu \mathrm{s} / \mathrm{cm}$ & 0.2 \\
\hline
\end{tabular}

329

Nonetheless, for the untreated feed solution with the $0.45 \mu \mathrm{m}$ membrane, pore breakthrough occurred after approximately 10 hours of operation. This is evidenced by the sudden and very rapid increase in flux at this point and the increase in conductivity within the permeate tank to $3.9 \mathrm{~ms} / \mathrm{cm}$. The LEP measured for the $0.45 \mu \mathrm{m}$ membrane using the B2 salty whey is very low at $55 \pm 11 \mathrm{kPa}$ (Figure 3). As the feed concentration increases during the filtration process, the LEP will decrease further, as noted in separate LEP measurements (Section 3.2). The accumulation of salts and trace protein on the membrane surface could further exacerbate this decline.

The flux begins to decline immediately for filtration of the untreated feed solution for the system employing the $0.45 \mu \mathrm{m}$ membrane. However, for all other cases, regions of relatively constant flux (with flux reduction less than $20 \%$ ) can be observed for some hours. This period of steady state operation is longer for the runs with protein (11 and 25 hours for the 0.2 and $0.05 \mu \mathrm{m}$ membranes) than those with no protein ( 6 and 10 hours). The longer period of steady state flux in these cases reflects the lower absolute value of this flux which means that the salt concentration increases more slowly. This is evident from Figure 6, which shows that the flux value for any particular salt concentration above $10 \mathrm{wt} \%$ is comparable, regardless of the protein concentration. As described above, the flux decline in the initial periods of distillation corresponds to a fall in the driving force i.e. water activity (Hausmann et al. 2013, Schofield et al. 1990, Yun et al. 2006), while in the final 
hours the flux is limited by the saturation concentration on the membrane surface and by a fouling layer.

Regardless of the membrane pore size, the experiments without protein residue can all achieve approximately $30 \pm 0.5 \% \mathrm{w} / \mathrm{w}$ total solids at the end of the MD experiment (Figure 6). The permeate quality can be maintained with salt concentrations in the permeate of $200 \mathrm{mg} /$ litre or below. At 30 wt\% solid concentration, the flux approaches zero, corresponding to the point at which salt crystallisation restricts the aqueous concentration to that given by the solid-liquid equilibria. Under these conditions, water can only evaporate as fast as salt can crystallise, in order to keep this aqueous concentration constant. This rate is below the level of detectable flux.

For the filtration with trace protein, the tighter pore membranes $(0.05$ and $0.2 \mu \mathrm{m})$ can similarly produce a concentrate with a solid concentration of $30 \pm 1.5 \% \mathrm{w} / \mathrm{w}$. Since liquid breakthrough occurs during filtration using the $0.45 \mu \mathrm{m}$ membrane, the solids concentration that can be achieved is limited to $21.8 \pm 1.1 \% \mathrm{w} / \mathrm{w}$.

\subsection{Effect of cross-flow velocity}

The experiments related to cross-flow velocity (CFV) were conducted using salty whey B2, after ultrafiltration in our laboratory to remove residual protein. With increasing CFV, both mass and heat transfer is enhanced due to reductions in concentration polarisation, which results in a higher permeate flux as depicted in Figure 7a. For a CFV of $0.2 \mathrm{~m} / \mathrm{s}$ the zero flux condition is achieved in approximately 15 hours of operation. Constant flux operation can be maintained for 3.9 hours followed by the steep flux decline which is characteristic of saturation being reached on the membrane surface.

371 At the lowest CFV $0.13 \mathrm{~m} / \mathrm{s}$, the constant flux region is observed for up to 13 hours, but after this, the curve shape differs from other experiments. The gentle decrease in flux might perhaps be due to 
fouling accumulation on the membrane, this is expected as a lower CFV would increase the susceptibility to fouling. The flux drop due to a reduction of water activity is observed at 15 hours.

At the initial conditions, i.e. a salt concentration of $<10 \% \mathrm{w} / \mathrm{w}$, increasing the CFV from 0.13 to 0.2 $\mathrm{m} / \mathrm{s}$ reduces the calculated concentration at the membrane surface $\left(c_{m}\right)$ from $110 \%$ to $107 \%$ of the bulk value (see Equation 4 and Figure 8). At the end of the filtration run, with the mixture solids concentration approaching $30 \% \mathrm{w} / \mathrm{w}$, increasing the CFV in this manner would decrease the membrane concentration from $113 \%$ to $109 \%$ of the bulk value, in turn, reducing the solids concentration on the membrane surface from $c_{m}, 0.13 \mathrm{~m} / \mathrm{s}=34.0 \% \mathrm{w} / \mathrm{w}$ to $c_{m}, 0.27 \mathrm{~m} / \mathrm{s}=32.7 \% \mathrm{w} / \mathrm{w}$. Nonetheless, the final total solid concentration of the retentate does not show a substantial difference, with the final concentration never exceeding approximately $30 \% \mathrm{w} / \mathrm{w}$. This may be because salt precipitation is occurring in the bulk solution rather than at the membrane surface. We often observed salt crystals in the final solution after overnight storage, indicative of such bulk precipitation. Conversely, it may be only because such changes are within the range of experimental error.

Operation at the highest CFV of $0.27 \mathrm{~m} / \mathrm{s}$ provides the highest fluxes, but there is clear evidence of pore breakthrough after 22 hours of operation. This is clear both from the sudden change in flux behaviour seen in Figure 7 and also a rapid increase observed in the permeate tank conductivity from $713 \mu \mathrm{s} / \mathrm{cm}$ to $3.9 \mathrm{~ms} / \mathrm{cm}$. Due to this issue, the solids concentration can only reach $28 \pm 0.3 \%$ wt\%. Such liquid breakthrough is likely be a major issue with operating at higher CFV at an industrial scale, as it can lead to significant pressure drop across the channel length, which in turn can reduce the transmembrane pressure below the LEP, particularly at high solute concentrations. 
The prediction of the pressure $\operatorname{drop}(\Delta \mathrm{P})$ across the channel length $(\mathrm{L})$ can be approximated using the correlation developed by Costa et al.(1994) (Da Costa et al. 1994, Koh et al. 2013). For a channelfilled spacer, this pressure drop is influenced by the turbulence generated by the complex geometry of the channel and spacer. The total drag $\left(C_{t d}\right)$ in the channel filled spacer is defined as (Da Costa et al. 1994):

Eq 7. $C_{t d}=4 f=\frac{2 \Delta \mathrm{PdH}_{H}}{\rho u_{\mathbb{K}}^{2} \mathrm{~L}}=\frac{A^{t}}{\operatorname{Re}^{\mathrm{n}}}$

Where $\mathrm{f}$ is the fanning friction factor, $\mathrm{d}_{\mathrm{H}}$ is the hydraulic diameter, $\rho$ the solution density and $\mathrm{u}_{\mathrm{x}}=\left(\frac{\text { CFV }}{\epsilon}\right)$ where $\varepsilon$ is the spacer porosity. $A^{\prime}$ and $n$ are fitted parameters based on the flow regime, spacer configuration and geometry.

Figure 9a shows the pressure drop determined both experimentally and from Equation 6 with respect to cross-flow velocity and solids concentration. The pressure drop increases exponentially with $\mathrm{n}$ determined to range from $0.31-0.37$ and $\mathrm{A}^{\prime}$ between 1.39 and 1.84 . This shows that the flow regime lays within the upper range of the transition region (Da Costa et al. 1994). Despite the $90^{\circ}$ spacer hydrodynamic angle that should generate high flow disturbance, the flow in the channel has not reached full turbulence. The increasing pressure drop with respect to the feed concentration is primarily due to changes in the feed properties i.e. higher density and viscosity (see Equation 6).

The discrepancies between the predicted and experimental data in Figure 9a might be associated with the error in the dial pressure gauge reading and also to the pressure drop within the angled configuration of the liquid entry point of the filtration cell. Further, all predicted data is generated using the physical properties of $\mathrm{NaCl}$ due to the lack of availability of data for the real industrial salty whey effluent used. This simplification is chosen as the concentration of $\mathrm{NaCl}$ outweighs other compounds. However, impurities in the system such as calcium phosphate and lactose might also influence the pressure drop. 
421 Comparing the pressure drop data to the LEP measurement, for the $0.2 \mu \mathrm{m}$ membrane, the LEP is

$422170 \pm 10 \mathrm{kPa}$ at the initial conditions. With increasing filtration time and solids concentration, the

423 hydrophobicity of the membrane would be compromised due to fouling deposition which leads to

424 the liquid penetration problem at $0.27 \mathrm{~m} / \mathrm{s}$ CFV.

425 While in the current bench scale experiments the pressure drop is not an issue in most experiments,

426 for larger and longer systems that would be required for a scaled up plant, this can lead to severe

427 breakthrough. To determine such effects in a $1 \mathrm{~m}$ length membrane module, the pressure drop

428 across the channel length is estimated using the same correlation (Figure 9b). Da costa et al (Da

429 Costa et al. 1994) has tabulated the parameters for various spacers commonly used in industry and

430 Conwed-1 (rhomboid, $\varepsilon=0.618, n=0.24 A^{\prime}=1.29$ ) was chosen in the present case to give an

431 example of how such a commercial unit may behave. As shown in Figure 9b, this results in a slightly

432 higher pressure drop than that predicted for the laboratory spacer. While the pressure drop may be

433 higher, the mass transfer coefficient might also be higher, allowing a lower CFV to be used for the

434 same results. However, it is readily apparent that in either case, the transmembrane pressure will

435 exceed the LEP values provided in Figure 3 for all pore sizes of 0.1 micron and above. Only the 0.05

436 micron pore size membrane is viable at this scale. To obtain optimum water flux without

437 compromising the product quality, a balance between the pore size and the CFV must be achieved.

\subsection{Effect of pH on product flux and membrane fouling}

440 Since fouling is a critical issue in membrane distillation, we also considered the impact of mineral

441 scaling. These experiments were carried out using salty whey B3 and B4 after further ultrafiltration

442 in our laboratory to completely remove the protein. Since the protein has been removed, any fouling

443 contribution in this case should be due to inorganic scaling. Further, as these samples had a low

444 titratable acidity of around $0.09 \pm 0.01 \% \mathrm{w} / \mathrm{v}(\mathrm{pH}$ measured as $4.5-4.9$, Table 1$)$, this scaling is 
more likely to occur than for Samples B1 or B2, as calcium salts are known to be more soluble in acidic solutions(Rice et al. 2009a, Rice et al. 2009b).

The mineral scaling was first observed using scanning electron microscopy as shown in Figure 10a. It is readily apparent that while some scaling is observed, it is not sufficient itself to cause the very low or zero flux observed in the MD experiments. Rather this result confirms that the loss of flux is related to the solution reaching saturation at the solid liquid surface. Once crystallisation is initiated, the solution concentration is limited to that corresponding to the solid-liquid equilibrium condition and further evaporation can occur only at the rate of solid precipitation.

Table 4. The mol ratio of redissolved minerals ( $\mathrm{Ca}, \mathrm{K}, \mathrm{Mg}$ and $\mathrm{P}$ ) relative to sodium( $\mathrm{Na}$ ) for the original sample (B4), the foulant layer after membrane distillation and this foulant layer after membrane distillation of an acidified solution, by the addition of of $10 \mathrm{ml}$ of $2 \mathrm{M} \mathrm{HCl}$ per $\mathrm{L}$ of sample.

\begin{tabular}{|l|c|c|c|c|c|}
\hline Mol ratio & Ca & K & Mg & Na & P \\
\hline Feed solution & 1 & 0.95 & 0.14 & 23 & 0.49 \\
Foulant Layer Run 1 $^{\mathrm{a}}$ & 1 & 0.06 & 0.04 & 1.6 & 1.00 \\
Foulant Layer Run 2 $^{\mathrm{b}}$ & 1 & 0.31 & 0.09 & 8.3 & 1.15 \\
Foulant Layer after Acidification $^{\text {a }}$ & 1 & 0.78 & 0.18 & 20 & 1.12 \\
\hline
\end{tabular}

${ }^{a}$ in this run, the experiment was stopped immediately the flux dropped to zero

$458 \mathrm{~b}$ In this run, the experiment continued for several hours after the recorded flux dropped to zero.

459 c. addition of $10 \mathrm{ml} 2 \mathrm{M} \mathrm{HCL}$ to sample $-\mathrm{pH} 1.8$ and 2.2 (to provide a contrast to the raw sample $\mathrm{pH} 4.5-4.9$ )

To quantify this scaling layer, it was then dissolved in $\mathrm{HNO}_{3}$ and the composition of metallic

calcium. However, the fouling layer removed from the membrane after membrane distillation contains significantly more calcium. It can be seen that the amount of sodium decreases to between despite the much higher concentration of $\mathrm{NaCl}$ in the system, calcium phosphate salts are a major foulant.

It is well known that the solubility of calcium phosphate salts is strongly dependent upon $\mathrm{pH}$, with solubility increasing in more acidic solutions (Rice et al. 2009a, Rice et al. 2009b). Hence, to 
471 determine if this mineral scaling could be avoided, a further trial was conducted, where the feed

472 solution was first acidified to $\mathrm{pH} 1.8$ by addition of $\mathrm{HCl}$ prior to membrane distillation. The

473 membrane surface appears considerably less fouled when this approach is used (Figure 10b). The

474 foulant layer from this experiment contained less calcium, with the ratio between $\mathrm{Na}$ :Ca closer to

475 the initial ratio in the solution. This suggests that the calcium phosphate scaling has indeed been

repressed. However, the total quantity of foulant does not change dramatically, as evident from

Table 5 which provides an estimate of the foulant coverage per square millimetre.

Table 5: The total quantity of selected minerals presented on the membrane after membrane distillation and after membrane distillation of an acidified solution, by the addition of $10 \mathrm{ml}$ of $2 \mathrm{M}$ HCl per L of sample.

\begin{tabular}{|c|c|c|c|c|c|c|}
\hline $\mathrm{mMol} / \mathrm{mm}^{2}$ & $\mathrm{Ca}$ & $\mathbf{K}$ & $\mathrm{Mg}$ & $\mathrm{Na}$ & $\mathbf{P}$ & Total \\
\hline Foulant Layer Run $1^{a}$ & 0.28 & 0.02 & 0.01 & 0.44 & 0.28 & 1.03 \\
\hline Foulant Layer Run $2^{b}$ & 0.20 & 0.06 & 0.02 & 1.63 & 0.23 & 2.14 \\
\hline Foulant Layer after Acidification & 0.05 & 0.04 & 0.01 & 0.91 & 0.05 & 1.06 \\
\hline
\end{tabular}

${ }^{a}$ in this run, the experiment was stopped immediately the flux dropped to zero

${ }^{b}$ In this run, the experiment continued for several hours after the recorded flux dropped to zero.

Furthermore, while the feed solution exhibited a ratio of $\mathrm{Ca}: \mathrm{P}=2: 1$; this fell to $1: 1$ in the foulant

layer, for both the unadjusted and the acidified feed solution. From the solubility data presented in

Table 4, hydroxyapatite, with the lowest solubility product, might be expected to precipitate first.

Nevertheless, some researchers argue that the formation of hydroxyapatite is preceded by brushite

$\left(\mathrm{CaHPO}_{4} \cdot 2 \mathrm{H}_{2} \mathrm{O}\right)$ or octacalcium phosphate $\left(\mathrm{Ca}_{4} \mathrm{H}_{(}\left(\mathrm{PO}_{4}\right)_{3}\right)$ when the supersaturation levels are high 
Table 6. Solubility of common calcium salts in dairy systems (Rice 2008, Walstra et al. 1984,

Marshall and Daufin 1995, Smith and Martell 2004).

\begin{tabular}{|c|c|}
\hline Salt name & Solubility product (Ksp, $\left.20^{\circ} \mathrm{C}\right)$ \\
\hline Dicalcium phosphate (monetite, $\mathrm{CaHPO}_{4}$ ) & $1.26 \times 10^{-7}$ \\
\hline Dicalcium phosphate dehydrate (brushite, $\mathrm{CaHPO}_{4} .2 \mathrm{H}_{2} \mathrm{O}$ ) & $2.6 \times 10^{-7}$ \\
\hline Octacalcium phosphate $\left(\mathrm{Ca}_{4} \mathrm{H}\left(\mathrm{PO}_{4}\right)_{3}\right)$ & $1.2 \times 10^{-47}$ \\
\hline Tricalcium phosphate $\left(\mathrm{Ca}_{3}\left(\mathrm{PO}_{4}\right)_{2}\right)$ & $1.15 \times 10^{-29}$ \\
\hline Hydroxyapatite $\left(\mathrm{Ca}_{5} \mathrm{OH}\left(\mathrm{PO}_{4}\right)_{3}\right)$ & $1.8 \times 10^{-58}$ \\
\hline Magnesium phosphate $\left(\mathrm{MgHPO}_{4} \cdot 3 \mathrm{H}_{2} \mathrm{O}\right)$ & $1 \times 10^{-4}$ \\
\hline
\end{tabular}

496

While acidification changed the nature of the mineral scaling, the effect of acidity on the flux is not significant (Figure 11a), consistent with the results in Table 5. It can be seen that with the addition of $10 \mathrm{ml}$ of $2 \mathrm{M} \mathrm{HCl}$ per litre, the flux is very similar to the unadjusted feed in the early stages of filtration, yet for $20 \mathrm{ml} \mathrm{HCl}$ the flux is slightly higher. Beyond 15 hours of operation, the more acidic system maintains a steady-flux of approximately 1.7 to $1.3 \mathrm{~kg} / \mathrm{m}^{2} \mathrm{~h}$ for some $5-10$ hours, whereas the flux of the unadjusted solution falls to zero. However, as shown in Figure $11 \mathrm{~b}$, the flux at any particular solids concentration changes little after acid addition and there is insignificant change to the final solids concentration. This indicates that this acidity adjustment is ultimately of no value since for all systems, liquid penetration is not observed and the salt rejection is maintained to be > $99 \%$.

\section{Conclusions}

Salty whey waste streams have been successfully concentrated from less than 10 wt\% solids to 30 wt\% solids using membrane distillation. Depending upon the initial solids concentrations in the feed stream, $37-83 \%$ of the water was recovered in a pure form. The permeate flux and hence the time required for the operation was affected by the presence of even small quantities of protein in the 513 solution. This flux was also affected by the crossflow velocity and the membrane pore size. While a 514 range of pore size membranes could be used at the laboratory scale, pressure drop calculations 515 suggested that a pore size of 0.05 micron or smaller is required at industrial scale to prevent liquid 

breakthrough. While the flux in the early periods of operation was dominated by the water activity, the final salt concentration appeared to relate to the solution reaching saturation and crystallisation of salts commencing. The addition of acid to the feed solution changed the nature of the salt crystallisation on the surface of the membrane, but had little impact on the final salt concentration or the flux. This indicates that while calcium scaling occurred, this was not the rate determining step

521 in this operation.

522

\section{Acknowledgements}

524 The salty whey was provided by an Australian dairy company and this contribution is gratefully 525 acknowledged. Funding from the Dairy Innovation Research Hub, an Industrial Transformation 526 Research Hub of the Australian Research Council (IH120100005) is also acknowledged. Judy Lee 527 acknowledges the support from an Australian Research Council Discovery Early Career Researcher 528 Award (DE120101567). 


\section{References}

533

534

535

536

537

538

539

540

541

542

543

544

545

546

547

548

549

550

551

552

553

554

555

556

557

558

559

560

561

562

563

564

565

566

567

568

569

570

571

572

Alkhudhiri, A., Darwish, N. and Hilal, N. (2012a) Membrane distillation: A comprehensive review. Desalination 287(0), 2-18.

Alkhudhiri, A., Darwish, N. and Hilal, N. (2012b) Treatment of high salinity solutions: Application of air gap membrane distillation. Desalination 287, 55-60.

Alklaibi, A.M. and Lior, N. (2005) Membrane-distillation desalination: Status and potential. Desalination 171(2), 111-131.

Angela, H., Peter, S., Todor, V., Elankovan, P., Nohemi, Q.-C., Mike, W. and Mikel, D. (2011) Direct Contact Membrane Distillation of Dairy Process Streams. Membranes (1), 48.

Bandini, S., Gostoli, C. and Sarti, G.C. (1992) Separation efficiency in vacuum membrane distillation. Journal of Membrane Science 73(2-3), 217-229.

Bandini, S. and Sarti, G.C. (1999) Heat and mass transport resistances in vacuum membrane distillation per drop. AIChE Journal 45(7), 1422-1433.

Blaschek, K.M., Wendorff, W.L. and Rankin, S.A. (2007) Survey of salty and sweet whey composition from various cheese plants in Wisconsin. Journal of Dairy Science 90(4), 2029 - 2034.

Bradford, M.M. (1976) A Rapid and Sensitive Method for the Quantitation of Microgram Quantities of Protein Utilizing the Principle of Protein dye Binding. Analytical Biochemistry 72, 248-254.

Burgoyne, A. and Vahdati, M.M. (2000) Direct Contact Membrane Distillation. Separation Science and Technology 35(8), 1257-1284.

Curcio, E. and Drioli, E. (2005) Membrane distillation and related operations - A review. Separation and Purification Reviews 34(1), 35-86.

Da Costa, A.R., Fane, D.E. and Wiley (1994) Spacer characterization and pressure drop modelling in spacer-filled channels for ultrafiltration. Journal of Membrane Science 87(1), 79-98.

Edwie, F. and Chung, T.S. (2012) Development of hollow fiber membranes for water and salt recovery from highly concentrated brine via direct contact membrane distillation and crystallization. Journal of Membrane Science 421-422 111-123.

Fane, A.G., Schofield, R.W. and Fell, C.J.D. (1987) The efficient use of energy in membrane distillation. Desalination 64(231-243).

Findley, M.E. (1967) Vaporization through Porous Membranes. Industrial \& Engineering Chemistry Process Design and Development 6(2), 226-230.

Fritzmann, C., Löwenberg, J., Wintgens, T. and Melin, T. (2007) State-of-the-art of reverse osmosis desalination. Desalination 216(1-3), 1-76.

Gostoli, C., Sarti, G.C. and Matulli, S. (1987) Low temperature distillation through hydrophobic membrane. Separation and Purification Reviews 22(855-872).

Gryta, M. (2012) Effectiveness of water desalination by membrane distillation process. Membranes 2(3), 415-429.

Gryta, M., Markowska-Szczupak, A., Bastrzyk, J. and Tomczak, W. (2013) The study of membrane distillation used for separation of fermenting glycerol solutions. Journal of Membrane Science 431, 1-8.

Hausmann, A., Sanciolo, P., Vasiljevic, T., Weeks, M. and Duke, M. (2012) Integration of membrane distillation into heat paths of industrial processes. Chemical Engineering Journal 211--212, 378-387. 
573 Hausmann, A., Sanciolo, P., Vasiljevic, T., Weeks, M., Schroën, K., Gray, S. and Duke, M. (2013)

574 Fouling mechanisms of dairy streams during membrane distillation. Journal of Membrane Science $575441(0), 102-111$.

576 Hsu, S.T., Cheng, K.T. and Chiou, J.S. (2002) Seawater desalination by direct contact membrane 577 distillation. Desalination 143(3), 279-287.

578 Kayet, M.S. and Matsuura, T. (2011) Membrane Distillation Principle and Application, Elsevier, 579 Amsterdam, The Netherlands.

580 Khawaji, A.D., Kutubkhanah, I.K. and Wie, J.-M. (2008) Advances in seawater desalination 581 technologies. Desalination 221(1-3), 47-69.

582 Khayet, M., Cojocaru, C. and García-Payo, C. (2007) Application of response surface methodology 583 and experimental design in direct contact membrane distillation. Industrial and Engineering 584 Chemistry Research 46(17), 5673-5685.

585 Khayet Souhaimi, M. and Matsuura, T. (2011) Membrane Distillation [electronic resource] : Principles 586 and Applications, Burlington : Elsevier Science, 2011.

587 Koh, L.L.A., Ashokkumar, M. and Kentish, S.E. (2013) Membrane Processing, pp. 73-106, Blackwell 588 Publishing Ltd.

589 Laganà, F., Barbieri, G. and Drioli, E. (2000) Direct contact membrane distillation: modelling and 590 concentration experiments. Journal of Membrane Science 166(1), 1-11.

591 Lawson, K.W. and Lloyd, D.R. (1997) Membrane distillation. Journal of Membrane Science 124(1), 159225.

593 Marshall, A. and Daufin, G. (1995) Physico-Chemical aspects of membrane fouling by dairy fluids. 594 International Dairy Journal 9504, 8-35.

595 Martínez-Díez, L. and Vázquez-González, M.I. (1999) Temperature and concentration polarization in 596 membrane distillation of aqueous salt solutions. Journal of Membrane Science 156(2), 265-273.

597 Martínez-Díez, L., Vázquez-González, M.I. and Florido-Díaz, F.J. (1998) Study of membrane 598 distillation using channel spacers. Journal of Membrane Science 144(1-2), 45-56.

599 Martínez, L. and Rodríguez-Maroto, J.M. (2007) On transport resistances in direct contact membrane 600 distillation. Journal of Membrane Science 295(1-2), 28-39.

601 Mulder, M. (1996) Basic Principles of Membrane Technology Second Edition, Kluwer.

602 Rice, G. (2008) Membrane separation of calcium salts from dairy ultrafiltraion permeates, The 603 University of Melbourne, Melbourne.

604 Rice, G., Barber, A., O'Connor, A., Stevens, G.W. and Kentish, S.E. (2009a) Fouling of NF membrane 605 by dairy ultrafiltration permeate. Journal of Membrane Science 330, 117-126.

606 Rice, G., Kentish, S.E., O'Connor, A., Barber, A., Philajamaki, A., Nystrom, M. and Stevens, G.W. 607 (2009b) Analysis of separation and fouling behaviour during nanofiltration of dairy ultrafiltration 608 permeate. Desalination 236, 23-29.

609 Schofield, R.W., Fane, A.G., Fell, C.J.D. and Macoun, R. (1990) Factors affecting flux in membrane 610 distillation. Desalination 77(0), 279-294.

611 Siminoni, M. (2010) Membrane stripping: Desorption of carbon dioxide from alkali solvents, The 612 University of Melbourne, Melbourne.

613 Smith, R.M. and Martell, A.E. (2004) Critically selected stability constant of Metal complexes, NIST 614 College Station, Texas A\&M University. 
615 Souhaimi, M.K. and Matsuura, T. (2011) Membrane Distillation : Principle and Applications, Elsevier, 616 Amsterdam, Netherlands.

617 Spanos, N., Patis, A., Kanellopoulou, D., Andritsos, N. and Koutsoukos, P. (2007) Precipitation of 618 calcium phosphate from simulated milk ultrafiltrate solutions. Crystal growth \& design 7(1), 25-29.

619 Tomaszewska, M. (2000) Membrane distillation - Examples of applications in technology and 620 environmental protection. Polish Journal of Environmental Studies 9(1), 27.

621 Tun, C.M., Fane, A.G., Matheickal, J.T. and Sheikholeslami, R. (2005) Membrane distillation 622 crystallization of concentrated salts-flux and crystal formation. Journal of Membrane Science 623 257(1-2), 144-155.

624 Van der Bruggen, B. and Vandecasteele, C. (2002) Distillation vs. membrane filtration: overview of 625 process evolutions in seawater desalination. Desalination 143(3), 207-218.

626 Varian (1991) Inductively-Coupled Plasma (ICP) Instruments at work : Guide to ICP/AAS Analytical 627 values.

628 Walstra, P., Jenness, R. and Badings, H.T. (1984) Dairy chemistry and physics, Wiley.

629 Wilkinson, K., Brooks, R. and Halliwell, D. (2004) Survey of dairy factory solid and liquid waste 630 management practices. Closing the Loop: An holistic approach to the management of dairy

631 processor waste streams. Dairy Industries Sustainability Consortium.

632 Yun, Y., Ma, R., Zhang, W., Fane, A.G. and Li, J. (2006) Direct contact membrane distillation 633 mechanism for high concentration $\mathrm{NaCl}$ solutions. Desalination 188(1-3), 251-262.

634 Zhang, J. (2011) Theoretical and experimental investigation of membrane distillation, Victoria 635 University, Victoria.

636 Zhang, J., Dow, N., Duke, M., Ostarcevic, E., Li, J.-D. and Gray, S. (2010) Identification of material and 637 physical features of membrane distillation membranes for high performance desalination. Journal of 638 Membrane Science 349(1-2), 295-303. 
Figure 1. Schematic diagram of the direct contact membrane distillation apparatus, counter-current configuration. $\mathrm{TT}=$ Temperature transmitter, $\mathrm{PT}=$ Pressure Transmitter

Figure 2. Examples of the protein present in the samples determined by SDS-PAGE using Sample B3. The first three channels are the permeate after both microfiltration and ultrafiltration (MF/UF); the next three channels are the permeate after microfiltration (MF) and the next three are a $1 / 8^{\text {th }}$ dilution of the raw sample. The final channel is a control, showing representative molecular weights.

Figure 3. The liquid entry pressure of water and commercial salty whey effluent (samples B1 and B2) before and after additional ultrafiltration (UF) in the laboratory. The measurements were conducted with a heated cell at $\approx 50^{\circ} \mathrm{C}$. The calculated LEP value for water is from Equation 2 using the surface tension of water at $50^{\circ} \mathrm{C}\left(6.79 \times 10^{-2} \mathrm{~N} / \mathrm{m}\right)$ and the water-membrane contact angle determined at room temperature $\left(123^{\circ}\right)$.

Figure 4. The flux behaviour during MD with a large amount of protein in the system $(2.4 \mathrm{~g} /$ litre, Sample B1), and a membrane pore size of $0.2 \mu \mathrm{m}$. Results are shown both for the sample as received from the factory and after further ultrafiltration (UF) in our laboratory. Cross-flow velocity $0.2 \mathrm{~m} / \mathrm{s}$, feed temperature $50^{\circ} \mathrm{C}$ permeate $10^{\circ} \mathrm{C}$.

Figure 5. The effect of trace protein $(0.3 \mathrm{mg} /$ litre, Sample B2) as a function of the membrane pore size (a) as received from the factory (b) After further ultrafiltration(UF) in our laboratory. Cross-flow velocity $0.2 \mathrm{~m} / \mathrm{s}$, operating temperature feed $50^{\circ} \mathrm{C}$ permeate $10^{\circ} \mathrm{C}$. $\mathrm{mg} /$ litre, Sample B2), before and after further ultrafiltration (UF) in our laboratory to remove residual protein. Cross-flow velocity $0.2 \mathrm{~m} / \mathrm{s}$, operating temperature feed $50^{\circ} \mathrm{C}$ permeate $10^{\circ} \mathrm{C}$. 
Figure 7. The effect of cross-flow velocity on permeate flux as a function of (a) time and (b) total solids concentration, for a membrane of $0.2 \mu \mathrm{m}$ pore size and Sample B2 after UF in our laboratory to remove residual protein. Operating temperature of feed $50^{\circ} \mathrm{C}$, permeate $10^{\circ} \mathrm{C}$.

Figure 8. The calculated concentration polarization ratio as a function of increasing solids concentration in the feed and cross-flow velocity for a membrane of $0.2 \mu \mathrm{m}$ pore size, sample B2 after UF in our laboratory to remove residual protein. Operating temperature feed $50^{\circ} \mathrm{C}$ permeate $10^{\circ} \mathrm{C}$

Figure 9. The pressure drop as a function of the total solids in the feed, with respect to the crossflow velocity for the $0.2 \mu \mathrm{m}$ membrane. Operating temperature feed $50^{\circ} \mathrm{C}$ permeate $10^{\circ} \mathrm{C}$. (a) Lab scale - the symbols represent experimental data, while the curves are fits to Equation 6 with $n=$ $0.31, A^{\prime}=1.39$. (b) Predicted values for a $1 \mathrm{~m}$ channel length using both the laboratory spacer and a typical industrial spacer.

Figure 10. SEM images of the mineral scaling following membrane distillation of salty-whey with titratable acidity $0.09 \% \mathrm{w} / \mathrm{v}$ (Sample B3) using a $0.2 \mu \mathrm{m}$ membrane and a cross-flow velocity 0.20 $\mathrm{m} / \mathrm{s}$. Operating temperature of feed $50^{\circ} \mathrm{C}$, permeate $10^{\circ} \mathrm{C}$. (a) Original Sample (b) Sample acidified to $\mathrm{pH} 1.8$ by the addition of $10 \mathrm{ml}$ of $2 \mathrm{M} \mathrm{HCl}$ per litre.

Figure 11. The permeate flux at different feed acidities as a function of (a) time and (b) total solids concentration for a membrane of $0.2 \mu \mathrm{m}$ pore size, with a cross-flow velocity $0.20 \mathrm{~m} / \mathrm{s}$. Operating temperature feed $50^{\circ} \mathrm{C}$ permeate $10^{\circ} \mathrm{C}$. The feed solutions were UF pre-filtered to eliminate trace protein.

Table 1. Composition of the salty-whey. 

protein) as a function of pore size.

690 Table 4. The mol ratio of redissolved minerals ( $\mathrm{Ca}, \mathrm{K}, \mathrm{Mg}$ and $\mathrm{P}$ ) relative to sodium( $\mathrm{Na}$ ) for the 691 original sample (B4), the foulant layer after membrane distillation and this foulant layer after 692 membrane distillation of solution acidified to $\mathrm{pH} 1.8$ by the addition of of $10 \mathrm{ml}$ of $2 \mathrm{M} \mathrm{HCl}$ per $\mathrm{L}$ of 693 sample.

694 Table 5: The total quantity of selected minerals presented on the membrane after membrane 695 distillation and after membrane distillation of an acidified solution, by the addition of $10 \mathrm{ml}$ of $2 \mathrm{M}$ $696 \mathrm{HCl}$ per L of sample.

697 Table 6. Solubility of common calcium salts in dairy systems (Marshall and Daufin 1995, Rice 2008, 698 Smith and Martell 2004, Walstra et al. 1984). 


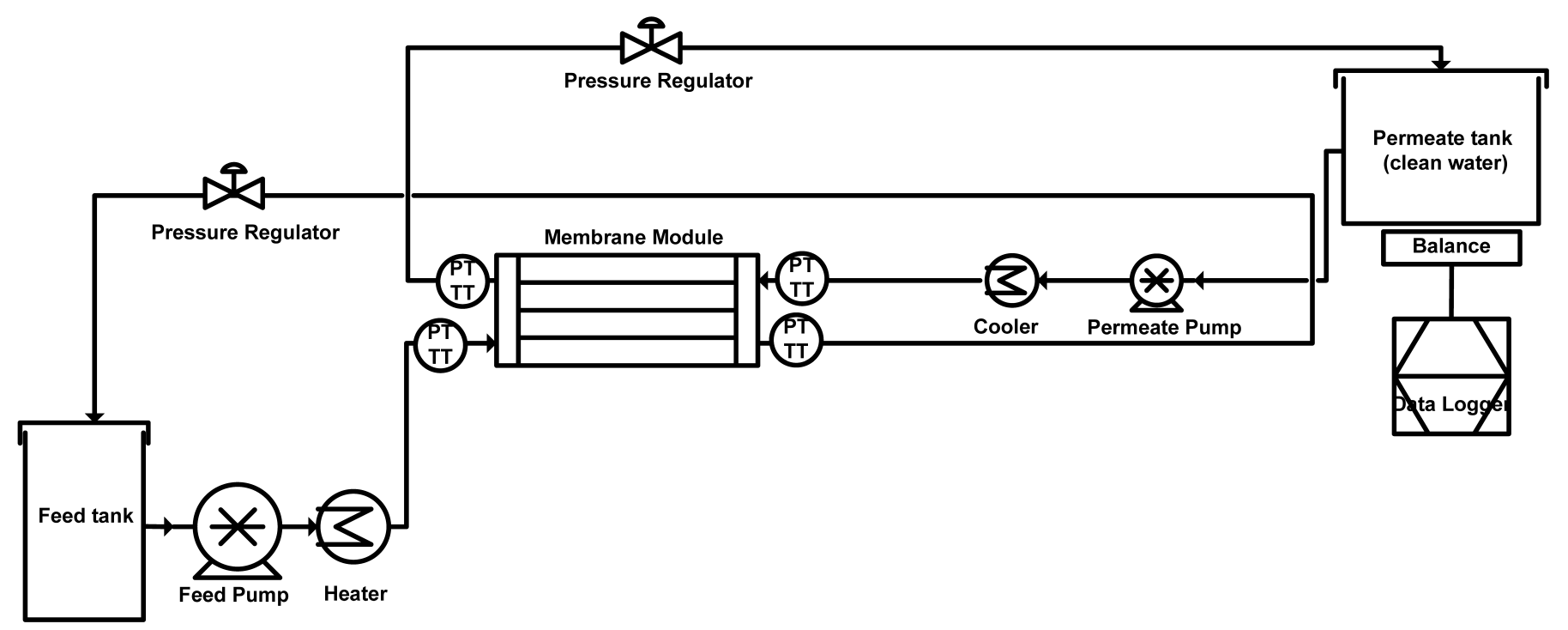

Figure 1. Schematic diagram of the direct contact membrane distillation apparatus, counter-current configuration. $\mathrm{TT}=$ Temperature transmitter, $\mathrm{PT}=$ Pressure Transmitter 


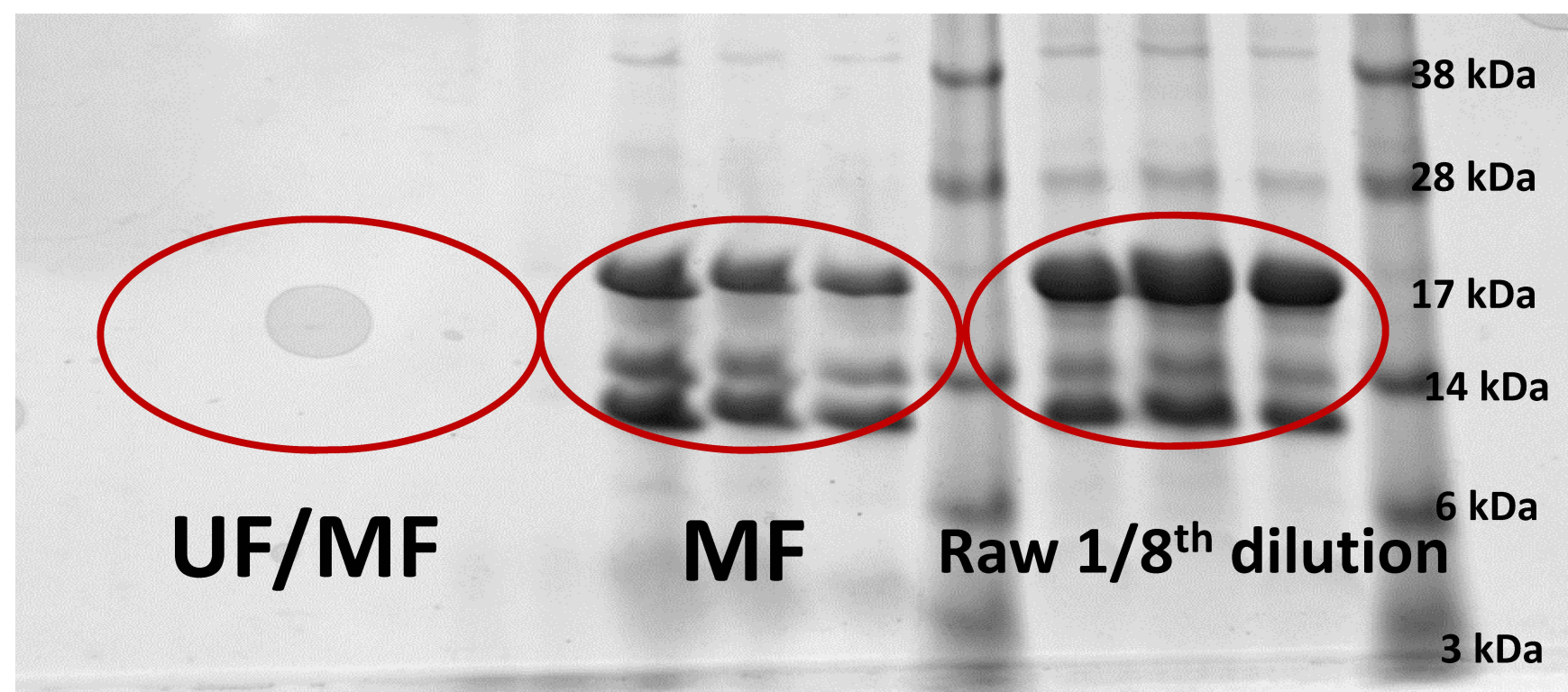

Figure 2. Examples of the protein present in the samples determined by SDS-PAGE using Sample B3. The first three channels are the permeate after both microfiltration and ultrafiltration (MF/UF); the next three channels are the permeate after microfiltration (MF) and the next three are a $1 / 8^{\text {th }}$ dilution of the raw sample. The final channel is a control, showing representative molecular weights. 


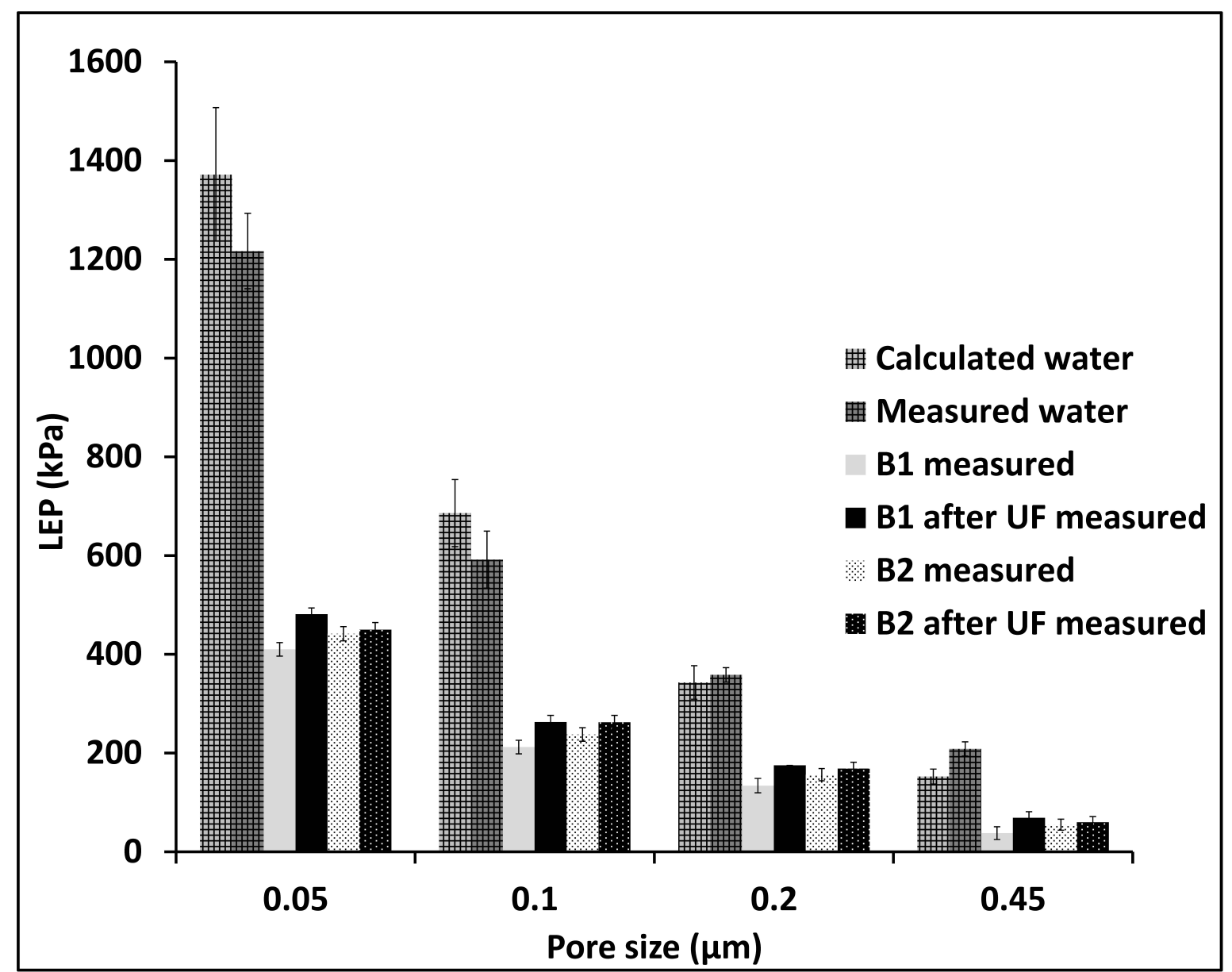

Figure 3. The liquid entry pressure of water and commercial salty whey effluent (samples B1 and B2) before and after additional ultrafiltration (UF) in the laboratory. The measurements were conducted with a heated cell at $\approx 50^{\circ} \mathrm{C}$. The calculated LEP value for water is from Equation 2 using the surface tension of water at $50^{\circ} \mathrm{C}\left(6.79 \times 10^{-2} \mathrm{~N} / \mathrm{m}\right)$ and the water-membrane contact angle determined at room temperature $\left(123^{\circ}\right)$. 


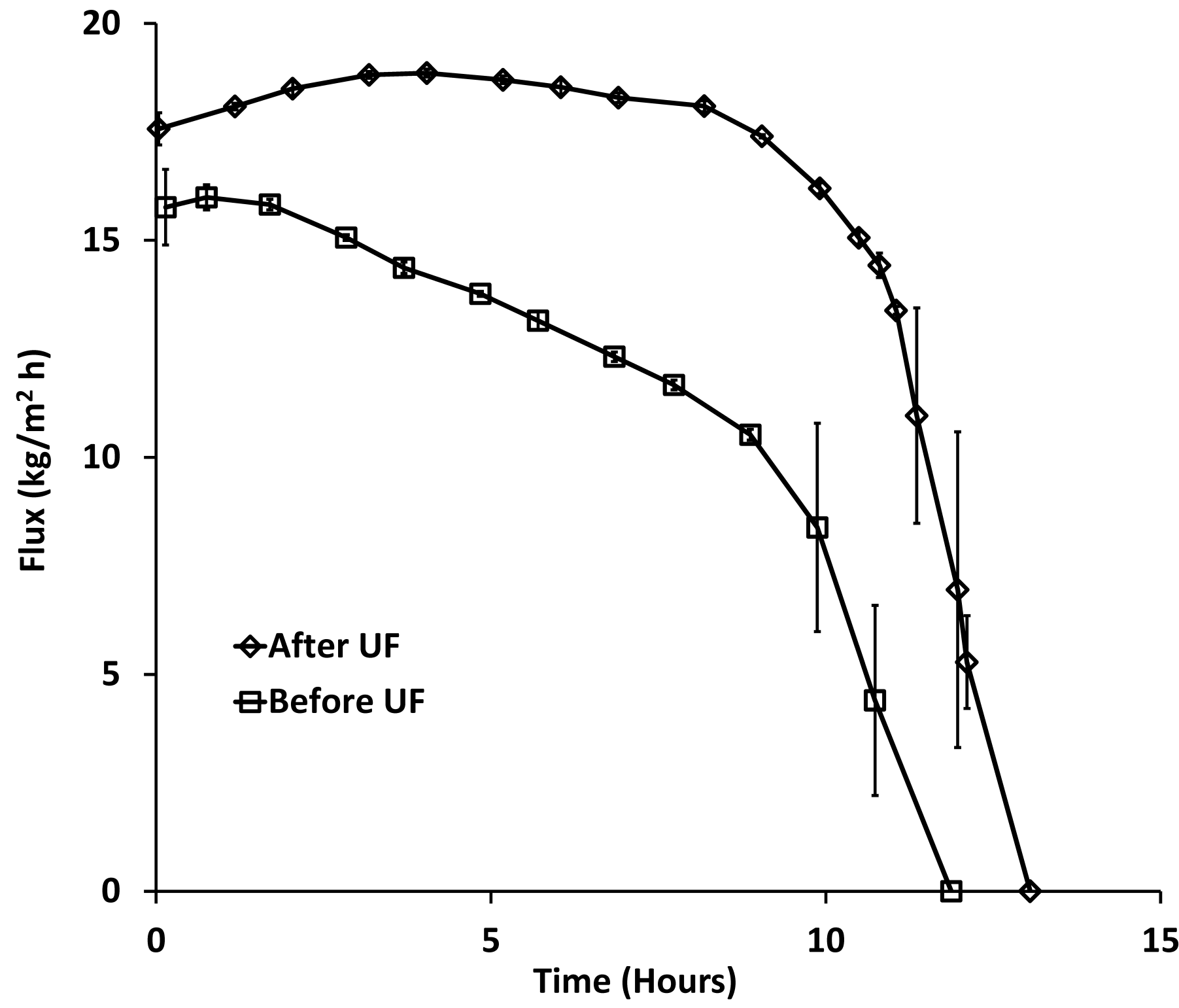

Figure 4. The flux behaviour during MD with a large amount of protein in the system (2.4 $\mathrm{g} /$ litre, Sample B1), and a membrane pore size of $0.2 \mu \mathrm{m}$. Results are shown both for the sample as received from the factory and after further ultrafiltration (UF) in our laboratory. Cross-flow velocity $0.2 \mathrm{~m} / \mathrm{s}$, feed temperature $50^{\circ} \mathrm{C}$ permeate $10^{\circ} \mathrm{C}$. 


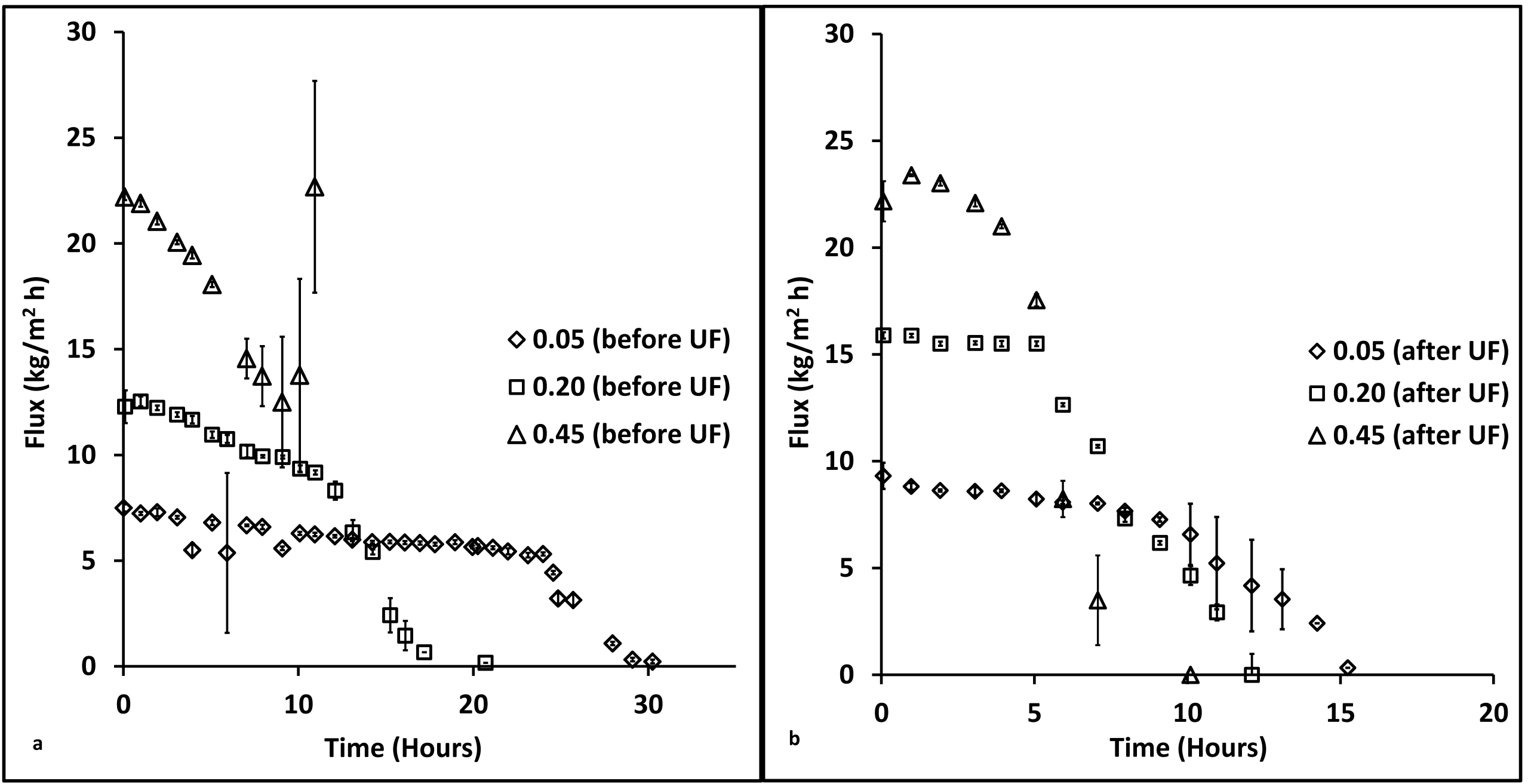

Figure 5. The effect of trace protein $(0.3 \mathrm{mg} /$ litre, Sample B2) as a function of the membrane pore size (a) as received from the factory (b) After further ultrafiltration(UF) in our laboratory. Cross-flow velocity $0.2 \mathrm{~m} / \mathrm{s}$, operating temperature feed $50^{\circ} \mathrm{C}$ permeate $10^{\circ} \mathrm{C}$. 


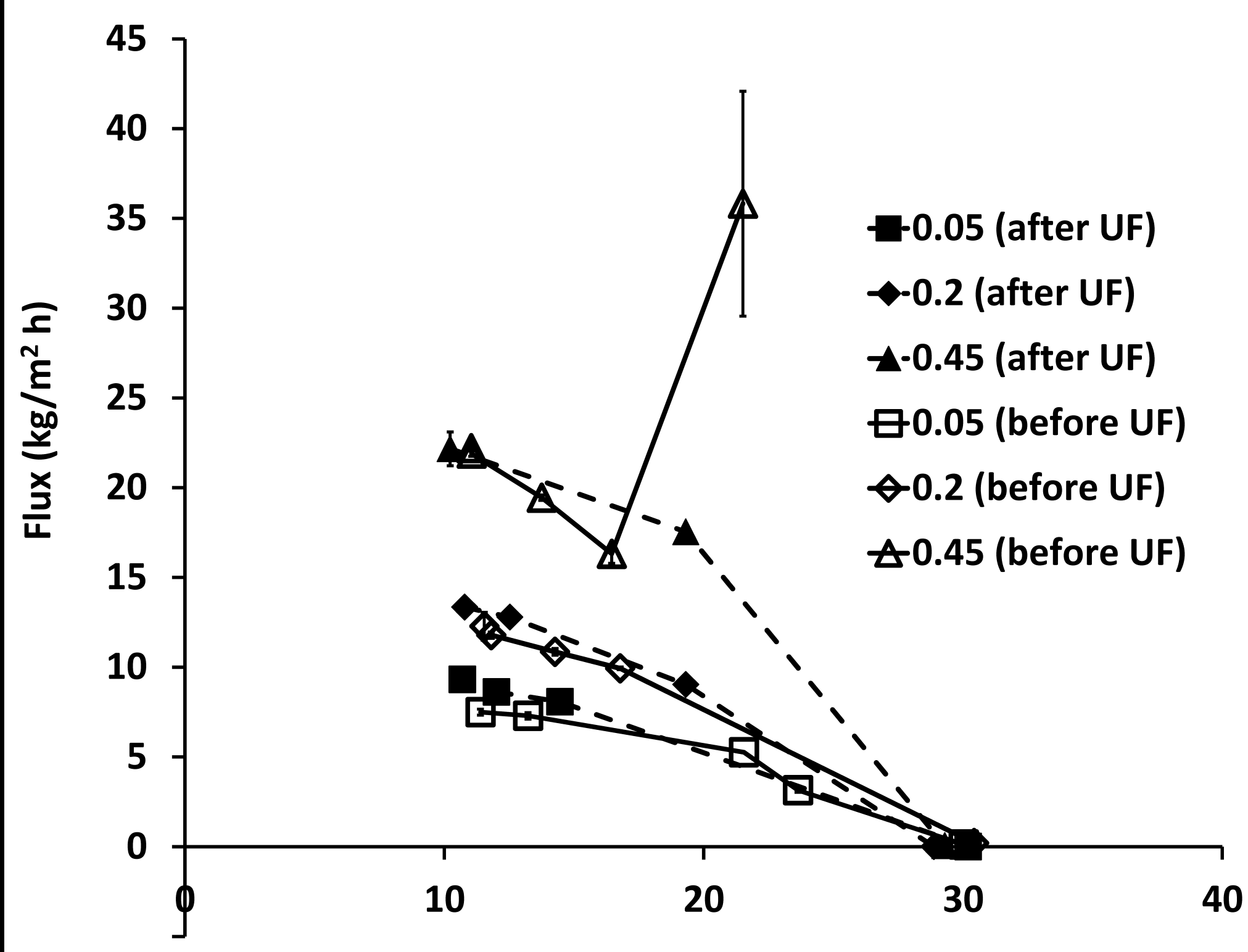

Feed Concentrate w/w (\%)

Figure 6. Permeate flux as a function of the total solids concentration during the MD process $(0.3 \mathrm{mg} /$ litre, Sample B2), before and after further ultrafiltration (UF) in our laboratory to remove residual protein. Cross-flow velocity $0.2 \mathrm{~m} / \mathrm{s}$, operating temperature feed $50^{\circ} \mathrm{C}$ permeate $10^{\circ} \mathrm{C}$. 


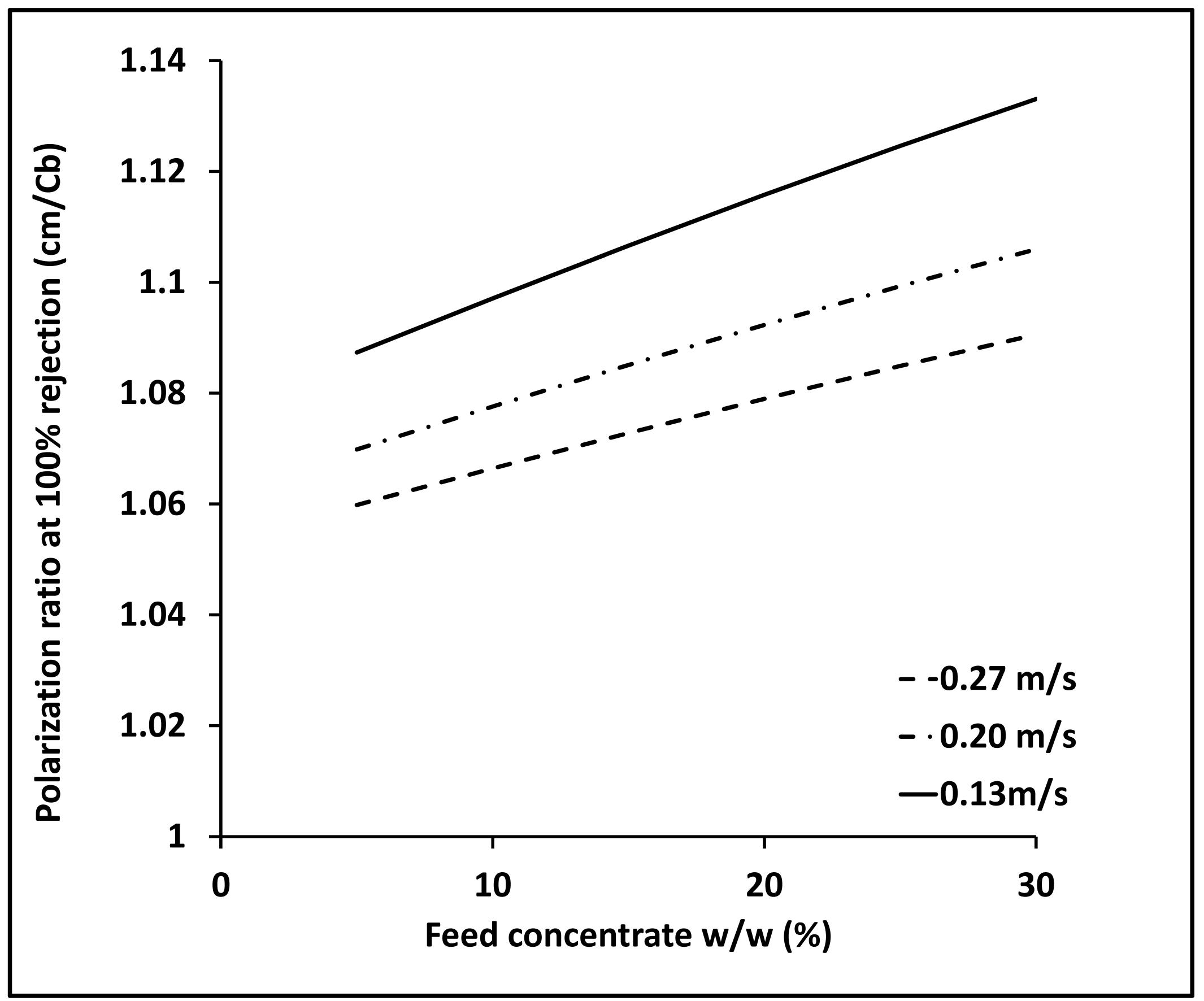

Figure 8. The calculated concentration polarization ratio as a function of increasing solids concentration in the feed and cross-flow velocity for a membrane of $0.2 \mu \mathrm{m}$ pore size, sample B2 after UF in our laboratory to remove residual protein. Operating temperature feed $50^{\circ} \mathrm{C}$ permeate $10^{\circ} \mathrm{C}$. 


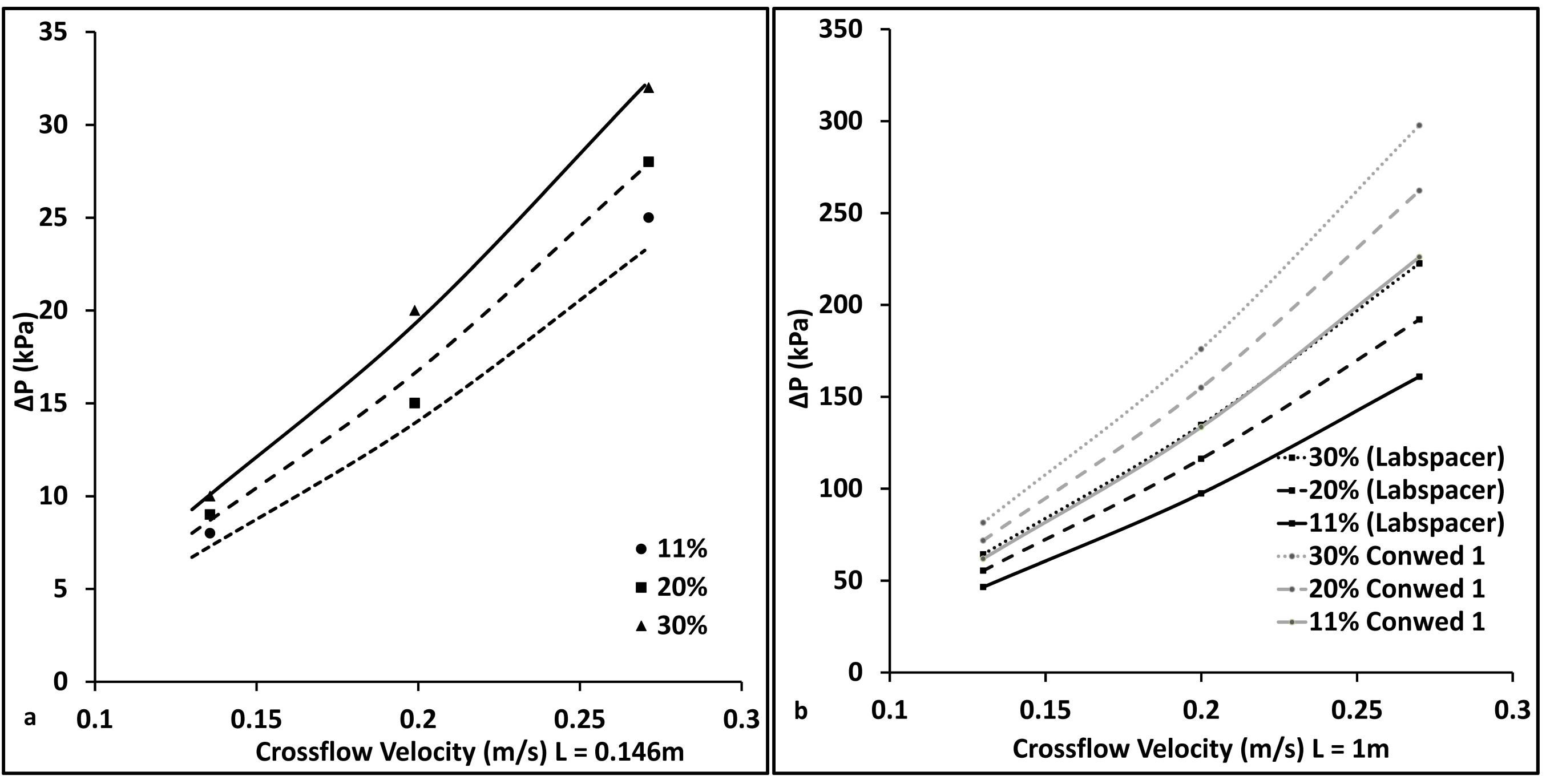

Figure 9. The pressure drop as a function of the total solids in the feed, with respect to the cross-flow velocity for the $0.2 \mu \mathrm{m}$ membrane. Operating temperature feed $50^{\circ} \mathrm{C}$ permeate $10^{\circ} \mathrm{C}$. (a) Lab scale - the symbols represent experimental data, while the curves are fits to Equation 6 with $n=0.31, A^{\prime}=1.39$. (b) Predicted values for a $1 \mathrm{~m}$ channel length using both the laboratory spacer and a typical industrial spacer. 


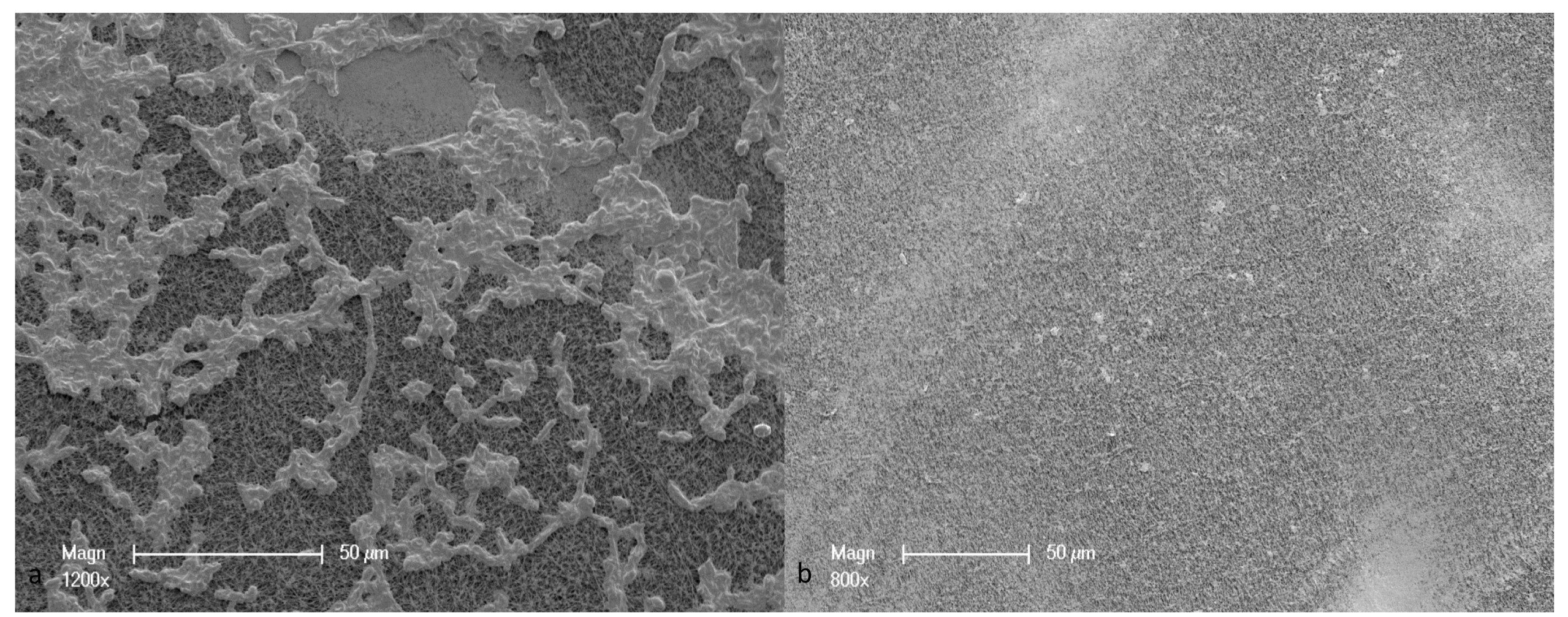

Figure 10. SEM images of the mineral scaling following membrane distillation of salty-whey with titratable acidity $0.09 \%$ $\mathrm{w} / \mathrm{v}$ (Sample B3) using a $0.2 \mu \mathrm{m}$ membrane and a cross-flow velocity $0.20 \mathrm{~m} / \mathrm{s}$. Operating temperature of feed $50^{\circ} \mathrm{C}$, permeate $10^{\circ} \mathrm{C}$. (a) Original Sample (b) Sample acidified by the addition of $10 \mathrm{ml}$ of $2 \mathrm{M} \mathrm{HCl}$ per litre. 


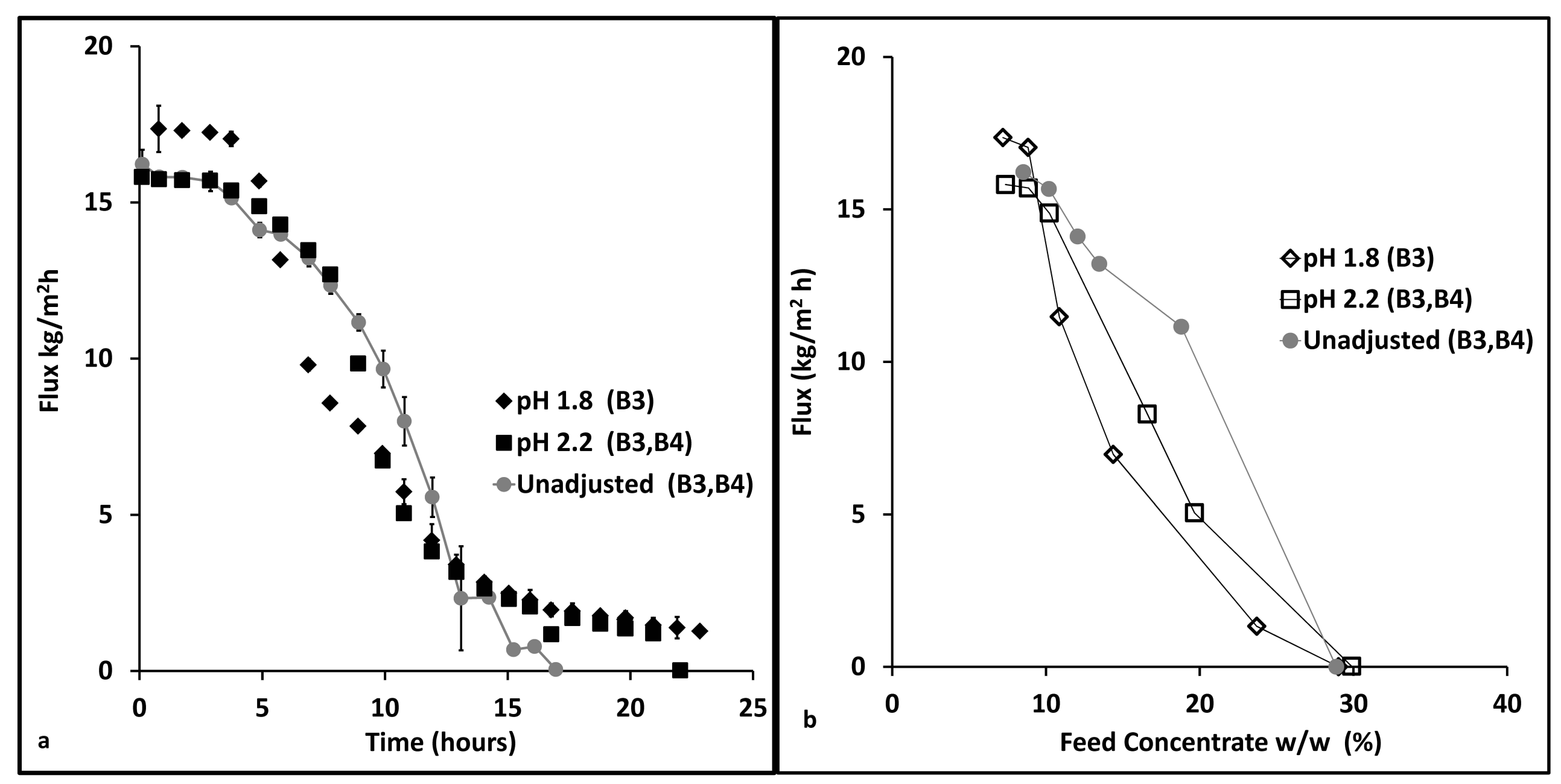

Figure 11. The permeate flux at different feed acidities as a function of (a) time and (b) total solids concentration for a membrane of $0.2 \mu \mathrm{m}$ pore size, with a cross-flow velocity $0.20 \mathrm{~m} / \mathrm{s}$. Operating temperature feed $50^{\circ} \mathrm{C}$ permeate $10^{\circ} \mathrm{C}$. The feed solutions were UF pre-filtered to eliminate trace protein. 